\title{
New Insights in Cardiac $\beta$-Adrenergic Signaling During Heart Failure and Aging
}

\section{Claudio de Lucia, Akito Eguchi and Walter J. Koch*}

Department of Pharmacology - Center for Translational Medicine, Lewis Katz School of Medicine, Temple University, Philadelphia, PA, United States

Heart failure $(\mathrm{HF})$ has become increasingly common within the elderly population, decreasing their survival and overall quality of life. In fact, despite the improvements in treatment, many elderly people suffer from cardiac dysfunction (HF, valvular diseases, arrhythmias or hypertension-induced cardiac hypertrophy) that are much more common in an older fragile heart. Since $\beta$-adrenergic receptor ( $\beta$-AR) signaling is abnormal in failing as well as aged hearts, this pathway is an effective diagnostic and therapeutic target. Both HF and aging are characterized by activation/hyperactivity of various neurohormonal pathways, the most important of which is the sympathetic nervous system (SNS). SNS hyperactivity is initially a compensatory mechanism to stimulate contractility and maintain cardiac output. Unfortunately, this chronic stimulation becomes detrimental and causes decreased cardiac function as well as reduced inotropic reserve due to a decrease in cardiac $\beta$-ARs responsiveness. Therapies which (e.g., $\beta$-blockers and physical activity) restore $\beta$-ARs responsiveness can ameliorate cardiac performance and outcomes during HF, particularly in older patients. In this review, we will discuss physiological $\beta$-adrenergic signaling and its alterations in both HF and aging as well as the potential clinical application of targeting $\beta$-adrenergic signaling in these disease processes.

\footnotetext{
Keywords: beta-adrenergic receptors, heart failure, cardiac aging, GRK2, pharmacology, sympathetic nervous system, cardiovascular system
}

\section{INTRODUCTION}

Heart failure (HF) is a leading cause of morbidity and mortality in western countries. Particularly, HF prevalence has increased to 6.5 million in Americans $\geq 20$ years of age (Benjamin et al., 2017). Over the last several years, there has been an increase in the incidence and prevalence of HF in the elderly, drastically impacting their survival rate and quality of life (Shakib and Clark, 2016; Ziaeian and Fonarow, 2016). HF represents the final common clinical event of numerous cardiovascular diseases (CVDs); coronary artery disease (CAD) followed by myocardial ischemia is the most common cause worldwide. It is extensively recognized that dyslipidemia, diabetes, hypertension, obesity, metabolic syndrome, and an inactive lifestyle are major risk factors for CAD and HF (Mozaffarian et al., 2016). Importantly, all these factors have a higher prevalence in the older population and age as well as age-related diseases, are a risk factor for CVDs (Niccoli and Partridge, 2012; North and Sinclair, 2012; de Lucia et al., 2013; Gacci et al., 2016). Undoubtedly, it is crucial to invest in therapies that are able to counteract the effects of HF on cardiac function and at the same time improve the alterations that are unique to the aging heart. In this regard, we will discuss the role of cardiac $\beta$-adrenergic signaling in HF and aging. During HF and aging, 
several neurohormonal mechanisms are activated in order to maintain cardiac output. The most important among these are the sympathetic nervous system (SNS) overdrive characterized by elevated circulating catecholamines (CAs) and Renin-Angiotensin-Aldosterone System hyperactivity (Mendzef and Slovinski, 2004; Conti et al., 2012). Interestingly, due to chronic stimulation by CAs, cardiac $\beta$-adrenergic receptor $(\beta-A R)$ responsiveness is altered in both HF and aging, and treatments (e.g., $\beta$-blockers and physical activity) that improve their signaling can ameliorate cardiac performance and outcomes during HF, particularly in older aged patients (Baxter et al., 2002; Leosco et al., 2007; Femminella et al., 2013; Rengo et al., 2013; Ferrara et al., 2014). However, despite considerable advances in preventive medicine and pharmacological treatments, heart disease still represents a severe clinical, social, and economic burden (Ponikowski et al., 2014). Hence, it is important to develop new drugs that will be able to further blunt cardiac dysfunction in elderly people with CVDs. Targeting $\beta$-AR signaling seems to be a wise choice since it is crucial for cardiac function and its manipulation has already been shown to be effective. In this review, we will primarily discuss cardiac $\beta$-adrenergic signaling at the molecular level and then we will specifically examine its role during HF and physiological aging. Finally, we will provide a translational and clinical perspective as well as future directions.

\section{CARDIAC $\beta$-ADRENERGIC SIGNALING}

\section{$\beta$-Adrenergic Receptors}

The SNS is one of two branches of the nervous system that is involved in the regulation of numerous homeostatic mechanisms including cardiac function (Lymperopoulos et al., 2013). The main function of the SNS is to stimulate the body's fight-or-flight response. The two molecules that are utilized in SNS signaling are the CAs epinephrine (Epi), released by the adrenal medulla, and norepinephrine (NEpi), also released by the adrenal medulla (minor) as well as from sympathetic nerve endings (de Lucia et al., 2014). These mediators circulate throughout the body and act on adrenergic receptors such as those expressed in the heart, eliciting a positive inotropic response. In diseased states including HF, elevated CA levels can cause detrimental effects on the heart including promoting maladaptive cardiac hypertrophy and cell death.

$\beta$-Adrenergic receptors are members of the $G$ protein-coupled receptor (GPCR) superfamily of receptors whose signaling plays a critical role in the regulation of the function and processes of the cardiovascular system. Presently, three subtypes of $\beta$-ARs have been characterized ( $\left.\beta_{1}-\mathrm{AR}, \beta_{2}-\mathrm{AR}, \beta_{3}-\mathrm{AR}\right)$ with a fourth $\left(\beta_{4}-\mathrm{AR}\right)$ remaining controversial (Gauthier et al., 1996; Zhu et al., 2011). Intracellular signaling of each $\beta$-AR has been summarized in Figure 1. The three subtypes have different affinities for different ligands, which allow variable activation of each subtype (Bristow et al., 1986; Lohse et al., 2003; Zhu et al., 2011). In the healthy human heart, there is approximately a $4: 1$ ratio of $\beta_{1}$-AR to $\beta_{2}-\mathrm{AR}$, with minimal expression of $\beta_{3}$ AR (Bristow et al., 1986; Moniotte et al., 2001). It has recently been confirmed that $\beta_{1}$-ARs are present in all cardiomyocytes (Myagmar et al., 2017). Interestingly, Myagmar et al. (2017) found that $\beta_{2}$-AR and $\beta_{3}$-AR are frequently absent in myocytes (detected in only $\approx 5 \%$ of myocytes) but are abundant in nonmyocyte cells (mainly endothelial cells in this study). On the other side, $\beta_{1}$-AR is expressed at a low level in non-myocytes (Myagmar et al., 2017). Both $\beta_{1}$-AR and $\beta_{2}$-AR activation lead to increased inotropy, lusitropy, and chronotropy (Brodde and Michel, 1999); however, persistent $\beta_{2}$-AR activation can lead to the reversal of these effects (Lefkowitz, 1998). $\beta_{3}-\mathrm{AR}$ is similar to $\beta_{2}$-AR in that regard, as it can have both stimulatory and inhibitory effects on the heart (Lefkowitz, 1998). $\beta$-ARs, like other GPCRs, consist of a seven-transmembrane-spanning receptor and are coupled to an intracellular heterotrimeric G-protein complex (Rockman et al., 2002). After agonist binding, the receptor undergoes a conformational change that induces an exchange of guanosine diphosphate (GDP) for guanosine triphosphate (GTP), causing dissociation of the now active $G_{\alpha}$ and $G_{\beta \gamma}$ protein subunits. The activated $G_{\alpha}$ subunit then regulates the effector molecules downstream of the receptor. The identity of the downstream effectors is determined by the subtype of $\beta$-AR that is activated (Rockman et al., 2002). While all $\beta$-ARs are associated with the stimulatory $G$ protein $\left(G_{\alpha s}\right)$ activation, it is known that $\beta_{2}$-AR and $\beta_{3}$-AR can be coupled to inhibitory $G$ protein according to studies which showed that their activity was pertussis toxin sensitive $\left(G_{\alpha i}\right)$ (Kohout et al., 2001; Rockman et al., 2002). The activation of the $\mathrm{G}_{\alpha \mathrm{s}}$ subunit leads to activation of adenylyl cyclase (AC), which in turn catalyzes the local conversion of adenosine triphosphate (ATP) into cyclic adenosine monophosphate (cAMP). The rise in cAMP then triggers protein kinase A (PKA) activation by binding to its regulatory subunits and allowing the catalytic subunit to function. PKA then acts as a nodal point and further initiates the phosphorylation of effector molecules and subsequently a functional response. Effector molecules that are phosphorylated by PKA include phospholamban, L-type calcium channels, contractile proteins, $\beta$-AR itself, as well as many others (Post et al., 1999; Rockman et al., 2002). Studies have shown that there are seven isoforms of AC found in mammalian tissue with the type 5 and 6 being the most predominant isoforms found in the heart (Post et al., 1999; Chen et al., 2012). ACs can be activated by $G_{\alpha s}$ signaling and deactivated by $G_{\alpha i}$ signaling. cAMP signaling compartmentalization is now an established concept of how this second messenger is able to differentiate between various pathways.

All three $\beta$-ARs have the ability to activate $G_{\alpha s}$. Therefore, there must be a system in place to differentiate the signals when the different receptors are activated. Both $\beta_{1}$-AR and $\beta_{2}$-AR activate $G_{\alpha s}$ and downstream, AC and PKA. Specific stimulation of $\beta_{1}$-AR can induce cardiac hypertrophy and/or promote cardiomyocyte apoptosis (Engelhardt et al., 1999). On the other hand, under stress conditions such as in hypoxia, $\beta_{2}$-AR specific stimulation activates the $\mathrm{G}_{\alpha \mathrm{i}}$ and phosphoinositol 3-kinase dependent anti-apoptotic pathway, which is not demonstrated in $\beta_{1}$-AR stimulation (Chesley et al., 2000). Interestingly, Epi increases cellular cAMP levels and is able to induce activation of glycogen phosphorylase (Chen et al., 2012). 


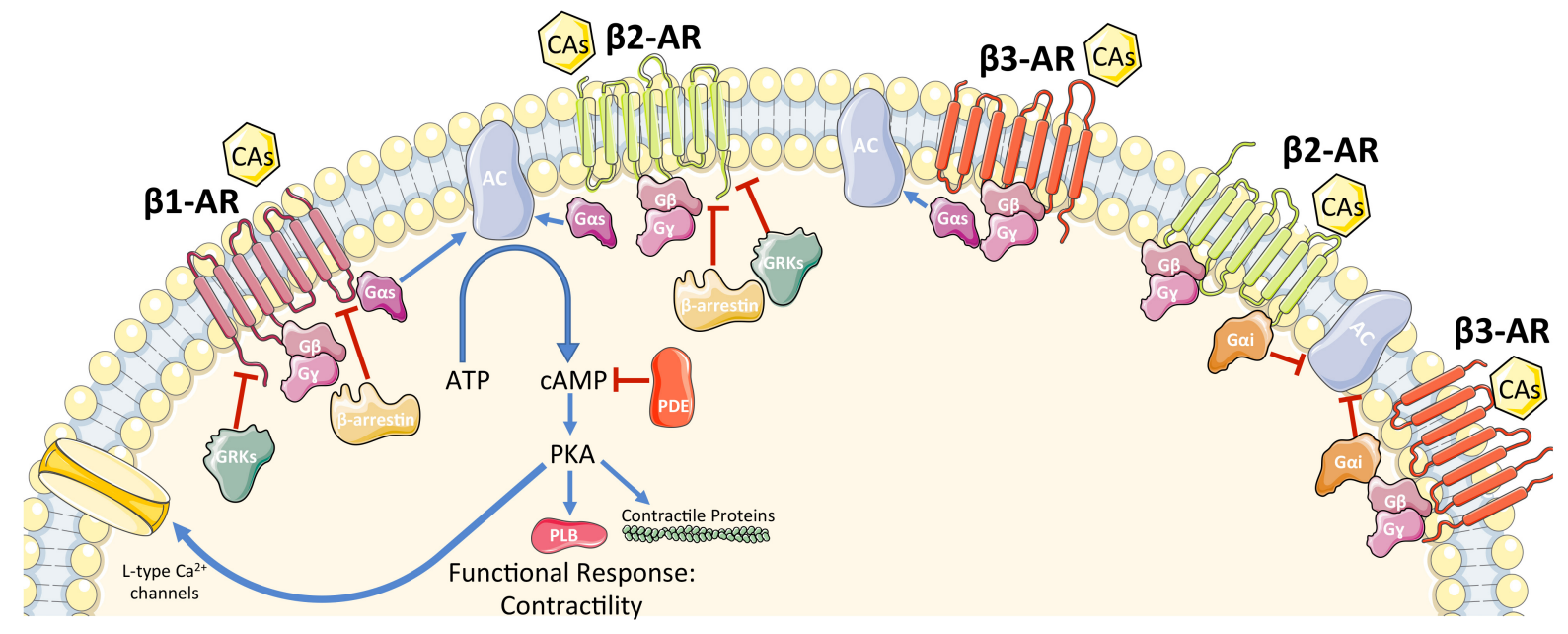

FIGURE 1 | Schematic representation of $\beta$-AR signaling in cardiomyocytes. See main text for details. CAs, catecholamines; $\beta$-AR, $\beta$-adrenergic receptor; G-protein subunits: $\mathrm{G}_{\alpha}\left(\mathrm{G}_{\alpha \mathrm{s}}\right.$ or $\left.\mathrm{G}_{\alpha \mathrm{i}}\right), \mathrm{G}_{\beta}, \mathrm{G}_{\gamma}$; GRK2, G protein-coupled receptor kinase 2; AC, adenylyl cyclase; ATP, adenosine tri-phosphate; cAMP, cyclic adenosine mono-phosphate; PDE, phosphodiesterase; PKA, protein kinase A. A blue arrow is used when a stimulatory mechanism is involved while a red bar-headed line is used for an inhibitory mechanism.

\section{GRKs, $\beta$-Arrestins, and Intracellular Signalosome}

Termination of the signal is accomplished at various steps throughout the $\beta$-AR pathways as a balance of activation and deactivation is critical for normal cellular functioning. $\beta$-ARs themselves can be deactivated and this is mainly accomplished through the actions of GPCR kinases (GRKs). GRKs are a family of seven serine/threonine protein kinases, which canonically recognize and phosphorylate agonist-activated GPCR's in order to terminate signaling (Sato et al., 2015). This recruits $\beta$-arrestins, which uncouple the receptor from G-proteins and promote internalization and down regulation of the receptor via a clathrin mediated process (Sato et al., 2015). Because of the sheer number of physiological processes mediated by GPCR's, including $\beta$-ARs, GRK's are crucial in maintaining cardiovascular homeostasis (Sato et al., 2015). Downstream of the receptors, $\beta$-arrestins can terminate signaling by recruiting phosphodiesterases (PDEs) and diacylglycerol kinase, which are involved in the breakdown of second messengers (Shenoy and Lefkowitz, 2011). $\beta$-arrestins are able to initiate signaling cascades independent of $G$ protein activation; $\beta_{2}$-AR can initiate ERK signaling both dependent on $G$ proteins as well as independent through $\beta$-arrestins (Patel et al., 2008). PKA is also able to induce both homologous desensitization as well as $\beta$-AR agonist independent-heterologous desensitization by phosphorylation of the receptor (Post et al., 1996, 1999).

The working paradigm regarding signal differentiation involves specific subcellular localizations that are isolated from each other. These distinct intracellular signaling compartments form "signalosomes" that mediate specific responses downstream of each receptor subtype (Lohse et al., 2003). There are numerous proteins that make up these signalosomes; however, the key members that regulate these include familiar names such as AC, PKA, PDEs as well as A kinase-anchoring proteins (AKAPs).
AKAPs are scaffolding proteins that assemble protein complexes including PKA and PDEs. These help to create subcellular compartments, which allows for precise spatiotemporal regulation (Tilley, 2011). PDEs break down cAMP into 5'-AMP and therefore act as another regulatory protein in maintaining tight control of local cAMP levels. In addition to AKAPs creating multiprotein complexes, physical compartmentalization of cAMP occurs via caveolae and T-tubules. Hence, understanding the complexity of $\beta$-AR signaling is fundamental for cardiac physiology and, as we will address in the following sections, for cardiac disease and physiological cardiac aging as well.

\section{$\beta$-ADRENERGIC SIGNALING IN HEART FAILURE}

\section{The Pathophysiology of Heart Failure}

Heart failure is a complex systemic syndrome that occurs when the heart is unable to provide tissues with adequate blood for their metabolic demands. This condition can result from alteration of systolic or diastolic function or, commonly, both. HF can be the end point of numerous CVDs such as $\mathrm{CAD}$ and following myocardial infarction (MI), hypertension, cardiomyopathies, valvular disorders, congenital heart diseases, rhythm abnormalities, and others. To counteract HF, it is crucial to understand the molecular mechanisms that interfere with the regulation of $\beta$-AR signaling (Figure 2). HF is characterized by hyperactivation of the SNS, leading to an increase in circulating CAs (NEpi and Epi) (Figure 2) from the adrenal medulla and augmented NEpi spillover from activated cardiac sympathetic nerve terminals into the circulation (Pepper and Lee, 1999; Lymperopoulos et al., 2013; de Lucia et al., 2014). SNS overactivity is initially a compensatory mechanism to maintain cardiac performance and stimulate contractility. 

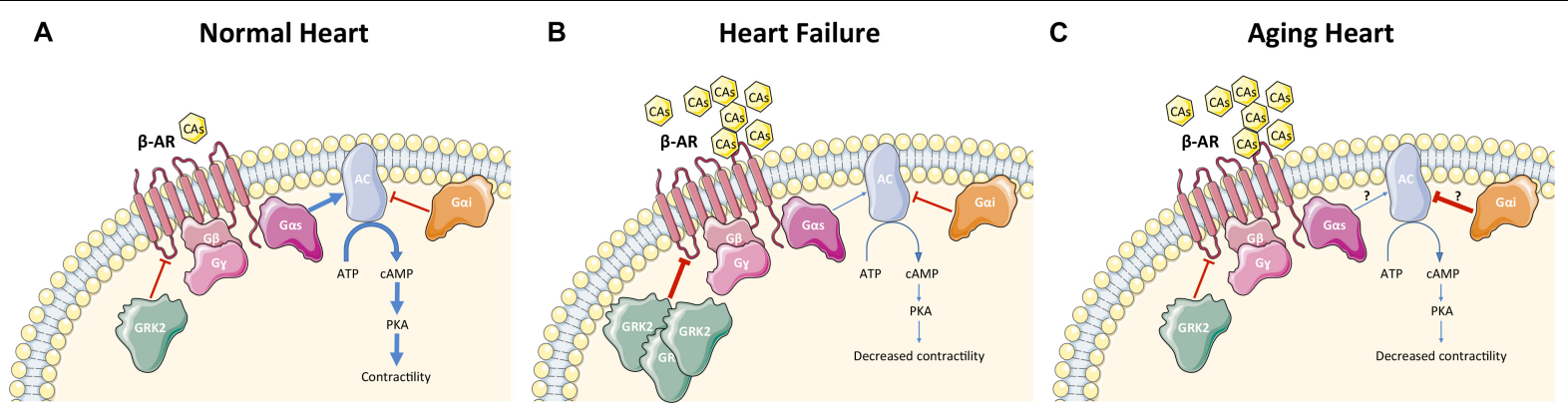

FIGURE 2 | $\beta$-AR signaling in cardiomyocytes under physiological condition (A), during heart failure (B), and during cardiac aging (C). Physiological conditions (A): GRK2 phosphorylates $\beta$-ARs in cardiomyocytes and regulates contractility via AC-PKA pathway activation. Heart failure (B): Increased circulating CAs led to hyper-stimulation of $\beta$-ARs and GRK2 upregulation in cardiomyocytes, resulting in desensitization/downregulation of $\beta$-ARs, ultimately leading to reduction of contractility. Aging heart (C): Aging is characterized by increased circulating CAs with desensitization/downregulation of cardiomyocyte $\beta$-ARs (GRK2 is unchanged and the mechanism of $\beta$-AR dysfunction is still unknown) and decreased contractility. AC activity is reduced leading to decreased levels of cAMP. CAs, catecholamines; $\beta$-AR, $\beta$-adrenergic receptor; G-protein subunits: $G_{\alpha}\left(G_{\alpha s}\right.$ or $\left.G_{\alpha i}\right), G_{\beta}, G_{\gamma}$; GRK2, $G$ protein-coupled receptor kinase 2; AC, adenylyl cyclase; ATP, adenosine tri-phosphate; cAMP, cyclic adenosine mono-phosphate; PKA, protein kinase A. A blue arrow is used when a stimulatory mechanism is involved while a red bar-headed line is used for an inhibitory mechanism. Thicker arrow means upregulation while thinner arrow means downregulation.

Unfortunately, this chronic stimulation becomes detrimental for $\beta$-ARs and causes dysfunction in their signaling, decreases cardiac contractility, as well as diminishes inotropic reserve (Bristow et al., 1982, 1986; Rengo et al., 2009a). In addition to regulation of contractility and excitation-contraction coupling, increased CAs negatively affect LV remodeling, fibrosis, and angiogenesis (Lymperopoulos et al., 2013; Ferrara et al., 2014). Importantly, ischemia-induced SNS overdrive affects metabolism and survival of cardiomyocytes particularly if associated to other cardiovascular risk factors such as hypertension and diabetes (Parati and Esler, 2012; Dei Cas et al., 2015). At the molecular level, myocardial $\beta$-AR dysfunction in HF is characterized by loss of $\beta_{1}$-AR density (around $50 \%$ ) at the plasma membrane (downregulation) and by uncoupling of the membrane $\beta_{1}$-ARs and $\beta_{2}$-ARs from $G$ proteins (desensitization) (Bristow et al., 1986; Ungerer et al., 1993) (Figure 2). When the role of $\beta$-ARs in diminished contractility in HF was first elucidated, the initial hypothesis was to increase inotropy through stimulation of cardiac $\beta$-ARs via agonists such as Epi, NEpi, and dobutamine as a clinical treatment for HF. However, the early enthusiasm diminished quickly, as patients either became hypertensive or arrhythmic after $\beta$-AR agonist therapy (Silver et al., 2002). These results, in combination with the demonstration of cardiac $\beta$-AR down-regulation in patients with HF, promoted the idea to study $\beta$-AR blockers in HF (Bristow et al., 1986; DiNicolantonio et al., 2015). $\beta$-blockers were initially used as a therapy to control HF-related tachycardia but surprisingly they were also found to significantly reduce mortality in patients with HF (Packer et al., 1996). $\beta$-blockers have been tested in numerous molecular and clinical studies, and they currently represent one of the cornerstones in the therapy of HF, though it is still debated whether they act by blocking or by resensitizing the $\beta$-AR system (Vinge et al., 2008).

\section{The Role of GRK2 in Heart Failure}

Importantly, it has been clearly shown both in humans and animal models that $\beta$-AR dysfunction in HF is GRK2-mediated:
SNS hyperactivity triggers GRK2 upregulation that is activated at the beginning to counteract the excessive catecholaminergic drive but later, elevated GRK2 levels leads to dysfunctional $\beta$-AR signaling and decreased contractility/inotropic reserve (Figure 2) (Post et al., 1999; Floras, 2002; Penela et al., 2006; Agüero et al., 2012; Rengo et al., 2012b; Sato et al., 2015). Hence, GRK2 inhibition has been proposed as a potential therapeutic target for HF (Lymperopoulos et al., 2012). Studies in a mouse model expressing the $\beta$ ARKct as a peptide inhibitor of GRK2 has confirmed this hypothesis. Particularly, transgenic mice that expressed $\beta$ ARKct showed enhanced cardiac contractility and increased sensitivity to acute $\beta$-AR stimulation (Koch et al., 1995). Conversely, cardiomyocyte-restricted overexpression of GRK2 at levels found in failing human myocardium (around threefold to fourfold) significantly decreased $\beta$-AR signaling and contractile reserve (Koch et al., 1995). Mice with cardiac $\beta A R K c t$ expression have also been shown to reverse ventricular dysfunction in several mouse models of HF (Freeman et al., 2001; Harding et al., 2001). In addition, in vivo inhibition of GRK2 only in cardiomyocytes, at or after birth, was able to ameliorate cardiac contractility and reverse adverse ventricular remodeling through improved $\beta$-AR signaling in an ischemic model of HF, confirming the specific pathological role of GRK2 in cardiomyocytes (Raake et al., 2008). Studies in rats, rabbit and large animals have further endorsed the potential applicability of GRK2 inhibition in clinical practice using viral-mediated $\beta$ ARKct gene therapy (White et al., 2000; Shah et al., 2001; Rengo et al., 2009b, 2012b). This includes pre-clinical studies using adeno-associated virusserotype-6 (AAV6)-mediated expression of $\beta$ ARKct in a porcine model of post-ischemic HF (Raake et al., 2013). In addition, paroxetine, a selective serotonin reuptake inhibitor (SSRI) that is currently used to treat depression and neuropsychiatric disorders, is also able to inhibit GRK2 as an off-target in the $\mu \mathrm{M}$ affinity range (Thal et al., 2012). HF mice chronically treated with this drug have been shown to improve left ventricular (LV) ejection fraction $(E F)$ and remodeling after MI. Our data showed that paroxetine reversed HF in mice due to its GRK2 inhibitory 
actions and were not related to its SSRI activity (Thal et al., 2012; Schumacher et al., 2015). Although paroxetine may not be a perfect candidate for HF therapy due to its well known mainly neurologic consequences, its beneficial effects in heart disease have stimulated medicinal chemists to develop selective small pharmacological agents that inhibits GRK2 (Powell et al., 2016; Waldschmidt et al., 2017).

Intriguingly, several molecules have been described to have GRK2 inhibitory properties such as RNA-aptamers or molecules that target the GRK2- $\mathrm{G}_{\beta \gamma}$ protein-protein interaction (M119 and Gallein) (Cannavo et al., 2013). Hence, GRK2 inhibition for the treatment of $\mathrm{HF}$ is not far from application in clinical trials: gene therapy with AAV6- $\beta$ ARKct will occur in the near future while GRK2 inhibition by small molecules would be an intriguing option, as well. $\beta$-ARKct expression and small molecules are known to target $\mathrm{G}_{\beta \gamma}$ binding, however, the main goal of cardiac GRK2 inhibition is to prevent phosphorylation-mediated $\beta$-AR dysfunction, and ultimately restore cardiac function (Sato et al., 2015). Inhibiting GRK2 to improve $\beta$-AR signaling in HF or aging appears counter-intuitive since $\beta$-blockers are effective in HF, however, GRK2 inhibition chronically up-regulates receptors in addition to resensitizing them, restoring normal $\beta$-AR contractile and metabolic signaling that essentially reestablishes the fightor-flight response and studies have shown this to be true with $\beta A R K c t$ and paroxetine lowering $\mathrm{Ca}^{2+}$ levels and SNS overactivity in HF models (Rengo et al., 2009b; Raake et al., 2013; Schumacher et al., 2015). This is actually part of the mechanism of $\beta$-blockers as well since they up-regulate receptors and improve signaling once activated (Sato et al., 2015). Studies with GRK2 inhibition coupled with a $\beta$-blocker in HF as shown in most models to be additive or even synergistic, also supporting non$\beta$-AR mechanisms involved in the therapeutic responses to GRK2 inhibitors (Sato et al., 2015). Moreover, our group has shown that GRK2 inhibition improved myocardial insulin signaling and cardiac metabolism in a model of ischemic HF (Ciccarelli et al., 2011).

\section{$\beta$-Adrenergic Receptors in Heart Failure}

Recently, our lab has shown that long-term caloric restriction normalized cardiac $\beta_{1}$-AR levels and improved cardiac inotropic reserve and sympathetic innervation in an animal model of ischemic HF (de Lucia et al., 2018a). Since it has been shown that $\beta_{1}$-AR downregulation is detrimental in HF, Engelhardt et al. (1999) studied if $\beta_{1}-\mathrm{AR}$ overexpression is positively affecting cardiac function. The authors showed that myocardial specific $\beta_{1}$ AR Transgenic ( $\mathrm{Tg}$ ) mice had increased cardiac contractility at a young age but after a few months developed marked myocyte hypertrophy and heart dysfunction (reduced EF). Moreover aged $\beta_{1}-\mathrm{AR}$ Tg mice showed increased levels of interstitial collagen type-I/III and augmented levels/activity of matrix metalloproteinase-2 associated with severe fibrosis (Seeland et al., 2007). Importantly, it is still debated if cardiac $\beta_{2}-A R$ overexpression is beneficial in HF. Several authors have shown that $\beta_{2}$-AR overexpression is able to ameliorate cardiac function in cardiac hypertrophy and HF (Dorn et al., 1999; Tevaearai et al., 2002; Rengo et al., 2012c). In fact, some authors showed that myocardial $\beta_{2}$-AR overexpression via gene delivery not only improved cardiac contractility and maladaptive remodeling but also increased angiogenesis in an animal model of HF (Rengo et al., 2012c). Other investigators demonstrated that cardiac $\beta_{2}-$ AR overexpression led to cardiac dysfunction, interstitial fibrosis, spontaneous onset of ventricular tachyarrhythmias (becoming more severe with aging), and higher mortality (Du et al., 2000; Nguyen et al., 2015). This latter result could be related to high $\beta_{2}$-AR levels (300-fold overexpression) and taken together with the data of Dorn et al. (1999), suggest that $\beta_{2}$-AR overexpression is probably beneficial only at a low-moderate level (Du et al., 2000). Interestingly, like many GPCRs, $\beta_{1}$-AR and $\beta_{2}$-AR can transactivate receptor tyrosine kinases such as epidermal growth factor receptor (EGFR). In particular, $\beta$-arrestins mediate $\beta_{1}$-AR signaling to the EGFR and this mechanism is independent of $G$ protein activation but involves GRK5 and GRK6 (Noma et al., 2007). In mice undergoing chronic sympathetic stimulation, this $\beta$-arrestin-biased signaling is shown to have a cardioprotective role, counteracting the effects of CAs toxicity. This research suggest that drugs that can antagonize $G$ protein-mediated signaling and at the same time stimulate the $\beta$-arrestin-mediated cardioprotective pathway, would be useful in pathologies where SNS overactivity is prominent, such as HF or diabetes-related cardiac disease (Noma et al., 2007; Iyngkaran et al., 2013; Lymperopoulos et al., 2013; Rengo et al., 2015). Besides, $\beta_{1^{-}}$ $\mathrm{AR}$ and $\beta_{2}-\mathrm{AR}$, the $\beta_{3}-\mathrm{AR}$ is found in cardiac myocytes with a characteristic coupling $\left(G_{\alpha s}\right.$ and $\left.G_{\alpha i}\right)$ and effects on cardiac function and remodeling (Moniotte et al., 2001; Balligand, 2013). In particular, $\beta_{3}-\mathrm{AR}$ is upregulated in cardiac diseases (both in human and animal models) and is less sensitive to desensitization compared to $\beta_{1}-\mathrm{AR}$ and $\beta_{2}$-AR (Dinçer et al., 2001; Moniotte et al., 2001; Balligand, 2013). Several groups have examined the effect of $\beta_{3}$-AR agonists in vivo in healthy animals or models of HF, with conflicting results. Some authors argue that $\beta_{3}$-AR agonists have a positive inotropic effect (mainly in HF models) (Donckier et al., 2001; Morimoto et al., 2004; Bundgaard et al., 2010; Balligand, 2016). Particularly, one of these studies found only a small negative inotropic effect in healthy sheep, but a significant improvement of inotropic parameters in sheep with HF. The latter in vivo effect was consistent with a beneficial effect of $\mathrm{Na}^{+}-\mathrm{K}^{+}$ATPase stimulation (Bundgaard et al., 2010). These different results from different groups, were possibly due to the type of $\beta_{3}$-AR agonist (diverse $\beta_{3}$-AR specificity) and dose of agonist used (high dose would potentially induce opposite effects compared to the low dose) (Balligand, 2016). Intriguingly, $\beta_{3}-\mathrm{AR}$ in cardiomyocytes, via-paracrine stimulation, influences surrounding cells (e.g., fibroblasts and endothelial cells). In particular, $\beta_{3}$-AR overexpression in myocytes reduced myocardial interstitial fibrosis and increased angiogenesis in response to isoproterenol/angiotensin II infusions as well as a $\beta_{3^{-}}$ AR agonist in mice submitted to transaortic constriction model (Niu et al., 2012; Belge et al., 2014; Balligand, 2016). Nevertheless, despite interesting results in basic research, Mirabegron (a $\beta_{3^{-}}$ $\mathrm{AR}$ agonist) did not increase $\mathrm{EF}$ or affect $\mathrm{LV}$ volumes in $\mathrm{HF}$ patients (results from the BEAT-HF trial) (Bundgaard et al., 2017). However, the authors did an exploratory sub-analysis showing an increase in EF in patients with severe HF at baseline, but not in patients with $\mathrm{EF} \geq 40 \%$. This analysis has been based 
on the hypothesis that $\beta_{3}-\mathrm{AR}$ agonist-induced $\mathrm{Na}^{+}-\mathrm{K}^{+}$ATPase stimulation is more effective in severe HF. Additional studies on the effects of $\beta_{3}$-AR agonists in patients with severe HF will clarify these results.

Interestingly, our lab has recently showed that $\beta_{3}$-AR dysfunction may be involved in patients that do not respond to $\beta_{1}$-AR-blockers (Cannavo et al., 2017). In fact, Metoprolol does not improve cardiac function (EF) and fibrosis in mice with $\beta_{3}$ AR deletion post-MI (Cannavo et al., 2017). $\beta_{1}$-AR blockade by Metoprolol leads to up-regulation of $\beta_{3}$-ARs, followed by the activation of sphingosine-1-phosphate (S1P) receptor signaling that appears protective and beneficial (Cannavo et al., 2017).

\section{$\beta$-Arrestins, Adenylyl Cyclases, and AKAPs in Heart Failure}

Another important component of $\beta$-AR signaling are $\beta$-arrestins (see above) and our group has studied their role in $\mathrm{HF}$. Particularly, $\beta$-arrestin 1 knockout (KO) mice have shown improved cardiac function (enhanced $\mathrm{EF}$ and inotropic reserve) in a model of ischemic HF: the underlying mechanisms are, on one side, improved cardiac $\beta$-AR signaling and function due to cardiac $\beta$-arrestin 1 deletion, and on the other, decreased circulating levels of CAs and aldosterone due to adrenal $\beta$-arrestin 1 absence (Lymperopoulos et al., 2011; Bathgate-Siryk et al., 2014). Contrasting data have been published on the effects of $\beta$-arrestin 2 manipulation during ischemic injury. $\beta$-arrestin $2 \mathrm{KO}$ mice showed lower survival compared to WT mice after MI due to enhanced macrophages-induced cardiac inflammation (Watari et al., 2013). In addition, $\beta$-arrestin 2 overexpression improved cardiac contractility and LV remodeling after $\mathrm{MI}$ through increased sarco[endo]plasmic reticulum $\mathrm{Ca}^{2+}$-ATPase (SERCA2a) activity (McCrink et al., 2017). On the other hand, Wang et al. (2017) showed that $\beta$-arrestin 2 KO mice are resistant to myocardial damage caused in an ischemia/reperfusion injury model. These dissimilar results on the role of $\beta$-arrestin 2 may be due to the different injury model used and related pathways involved. In this regard, further studies are necessary to understand if $\beta$-arrestin 2 deletion or overexpression is beneficial in ischemic HF.

Furthermore, it has been hypothesized that interrupting distal mechanisms in the $\beta$-AR-G protein-AC pathway may also be a therapeutic target in HF (Ho et al., 2010). Deletion of AC type 5 improves survival and protects against chronic pressure overload, chronic $\beta$-AR stimulation or enhanced $\beta$-AR signaling (mice with overexpressed $\beta_{2}-\mathrm{AR}$ ) via-anti apoptotic and antioxidative mechanisms (Okumura et al., 2003, 2007; Yan et al., 2014). In addition, activation of cardiac AC type 6 in mice with ischemic injury, improved LV systolic and diastolic function (enhanced EF and increased slope of the end systolic pressurevolume relationship - ESPVR), and decreases apoptosis (Lai et al., 2008). These studies suggest that AC type 5 inhibition or AC type 6 activation would be interesting therapeutic approaches in HF.

Mitochondrial AKAPs (mainly AKAP1) have been demonstrated to influence mitochondrial function and reactive oxygen species production in the heart. AKAP1 deletion led to mitochondrial alterations, enhanced mitophagy and increased infarct size as well as LV pathological remodeling in a model of post-ischemic HF (Schiattarella et al., 2016). In addition, AKAP5 deletion caused cardiac dilatation and dysfunction via enhanced activity of calmodulin kinase II/calcineurin and altered recycling of cardiac $\beta_{1}$-ARs (Li et al., 2014). Thus, AKAPs might represent another important player in cardiac pathophysiology.

\section{Cross-Talk Between Beta-Adrenergic and Insulin Signaling in Heart Failure}

It has also been reported that the prevalence of diabetes is augmented in patients with $\mathrm{HF}$ and hyperglycemia/hyperinsulinemia can strongly contribute to the impairment of cardiac function as well as worsen prognosis (Dei Cas et al., 2015; Jia et al., 2016; Komici et al., 2018). Furthermore, an insulin-resistant state (insulin resistance in both cardiac and peripheral tissues) seems to occur as a consequence of increased circulating CAs, in HF patients (Paolisso et al., 1991; Shimizu et al., 2012; Fu et al., 2017). In this regard, it is not surprising that both $\mathrm{HF}$ and diabetic patients show SNS overactivity (Lymperopoulos et al., 2013; Han et al., 2016). The insulin receptor (Ins-R) and $\beta$-AR cross talk, share similar down-stream signaling components, such as $G_{\alpha i}, \beta$-arrestins and GRK2, and counter-regulate each other (Song et al., 2001; Morisco et al., 2005; Cipolletta et al., 2009; Garcia-Guerra et al., 2010; Mangmool et al., 2016; Fu et al., 2017). This strict interaction was further clarified when a direct interaction in a membrane complex was found between Ins- $\mathrm{R}$ and $\beta_{2}$-AR (Mandić et al., 2014). Acute cardiac $\beta$-AR activation potentiates insulin-induced Akt-mediated glucose uptake via PKA, while chronic $\beta$-AR stimulation leads to insulin resistance (characterized by sustained Akt activation and reduced Glucose transporter type 4 -GLUT4- membrane levels) and ultimately impaired glucose uptake (Morisco et al., 2005; Mangmool et al., 2016; Fu et al., 2017). On the other hand, it has been shown that chronic insulin stimulation directly impairs cardiac $\beta$-AR signaling in mice (Fu et al., 2014, 2015). Interestingly, insulin elicits GRK2 recruitment to the plasma membrane and following $\beta_{2}$-AR phosphorylation/internalization, eventually reduces cAMP-PKA activity and contractile response in cardiomyocytes (Fu et al., 2015). Insulin receptor substrate 2 (IRS2) is crucial for the interaction between GRK2 and Ins-R (Fu et al., 2015). In addition, insulin stimulation induces PKA phosphorylation of the $\beta_{2}$-AR as well as $\beta_{2}$-AR coupling to $G_{\alpha i}$ (Fu et al., 2014). GRK2 is emerging as a key link to connect cardiac insulin and adrenergic signaling, as this kinase on one side can be upregulated by CAs and/or hyperinsulinemia and, on the other, phosphorylates and desensitizes both $\beta$-AR and Ins- $R$ (Ciccarelli et al., 2011; Fu et al., 2015, 2017; Mayor et al., 2018). In addition, cardiac GRK2 levels increase, not only during HF, but also in insulin resistance status such as in ob/ob mice or animals fed with high fat diet (Lucas et al., 2014). Our group has shown that GRK2 impairs cardiac glucose uptake and promotes insulin resistance after myocardial ischemia in an animal model, confirming that GRK2 could be an important hub in the regulation of cardiac function and metabolism during cardiac stress (Ciccarelli et al., 2011; Woodall et al., 2014; Mayor et al., 2018). Further, GRK2 downregulation enhances basal 
cardiac insulin sensitivity and ameliorates insulin resistance in an animal model of high-fat diet-induced obesity (Lucas et al., 2014; Vila-Bedmar et al., 2015). GRK2 is also involved in insulin signaling/IR dysfunction in other tissue as its levels are increased in muscle and adipose tissue in the animal models of insulin resistance as well as in lymphocytes from patients with metabolic syndrome (Garcia-Guerra et al., 2010). Moreover, GRK2 KO mice displayed protection and enhanced insulin sensitivity in animal models of obesity and TNF $\alpha$-induced insulin resistance (Garcia-Guerra et al., 2010). Diabetic patients are more likely to have infections and develop sepsis (Schuetz et al., 2011). GRK2 plays an important role in the pathogenesis and outcomes of sepsis in both animal models and patients by regulating inflammation and immune system (Packiriswamy and Parameswaran, 2015). The role of GRK2 as crucial node between HF and diabetes has been confirmed in humans as well. In fact, lymphocyte GRK2 protein levels are significantly increased in patients with diabetes mellitus and HF compared to failing non-diabetics patients, suggesting further compromised cardiac $\beta$-AR signaling/function (Rengo et al., 2015). Of note, myocardial GRK2 expression and activity are mirrored by lymphocyte levels of this kinase and consequently, lymphocyte GRK2 may be an adequate surrogate for monitoring cardiac GRK2 in human HF (Iaccarino et al., 2005). Incretin mimetics and inhibitors of the protease dipeptidyl peptidase-4 (DPP-4) are new promising classes of anti-diabetic agents that improve insulin sensitivity and pancreatic beta-cell function (Namba et al., 2013; Tasyurek et al., 2014). Interestingly, DPP-4 inhibition reduced isoproterenol-induced cardiomyocyte hypertrophy and perivascular fibrosis ameliorating cardiac glucose metabolism and inflammation in rats (Miyoshi et al., 2014).

\section{$\beta$-ADRENERGIC SIGNALING IN AGING HEART}

\section{The Pathophysiology of Aging Heart}

Cardiac aging in healthy individuals is characterized by numerous pathophysiological changes affecting the heart at the structural, histological, molecular and functional level. Structural changes primarily include LV remodeling, valvular changes, and modification in the conduction system while histologic changes involve fibrosis and modifications of extracellular matrix as well as cardiomyocyte death and hypertrophy (Boyle et al., 2011; Dai et al., 2012; Ferrara et al., 2014). At the molecular level cardiac aging shows altered excitation-contraction coupling and increased oxidative stress. The aforementioned alterations are closely recapitulated in animal models used in aging studies (Chiao and Rabinovitch, 2015). Functional alterations typically involve diastolic function while age-related systolic dysfunction is still controversial (Strait and Lakatta, 2012; de Lucia et al., 2018 b). It has recently been shown in both healthy patients and aging animal model that systolic function evaluated with speckle-tracking analysis was impaired (Crendal et al., 2014; de Lucia et al., 2018b). Importantly, in the senescent heart, sympathetic activity is increased while cardiac neuronal uptake of CAs is decreased (Tsuchimochi et al., 1995; Ferrara et al.,
2014). Age-dependent $\beta$-AR dysfunction is characterized by reduction in receptor density (White et al., 1994; Cerbai et al., 1995; Ferrara et al., 2014). $\beta$-adrenergic desensitization during aging causes reduced exercise tolerance, altered LV inotropic reserve, arterial-ventricular load mismatching, and physical deconditioning (Davies et al., 1996; Ferrara et al., 2014). In fact, the effects of aging are most evident during an exercise stress test which shows an overall decline in $\mathrm{VO}_{2} \max$ and cardiac index (Leosco et al., 2013). In addition, older healthy patients have a lower increase in heart rate during exercise and are less susceptible to $\beta$-blockade compared to young people (Ferrara et al., 2014; Nakou et al., 2016).

\section{Molecular Mechanisms in Cardiac Aging: Role of $\beta$-Adrenergic Signaling}

Although changes in $\beta_{1}$ - and $\beta_{2}$-AR agonist response in the failing and aging human heart are quite similar, GRKs expression and activity seem to be unaffected by age (Xiao et al., 1998; Leineweber et al., 2003) (Figure 2). Hence, the main cellular mechanism for reduced cardiac $\beta$-AR responsiveness during aging is unknown. It is hypothesized that there is another mechanism other than GRKs that determines dysfunctional $\beta$-AR signaling during the aging process. Importantly, contrasting results have been published about cardiac $\mathrm{G}_{\alpha \mathrm{i}}$ levels content and activity. In one study, $G_{\alpha i}$ levels were measured in atrial tissues received from cardio-surgical patients and it was found that $\mathrm{G}_{\alpha \mathrm{i}}$ expression increased with age (Brodde et al., 1995a,b). Agedependent $\mathrm{G}_{\alpha \mathrm{i}}$ upregulation has been shown in animal models (rat), as well (Böhm et al., 1993). Oppositely, Xiao et al. (1998) reported that $\mathrm{G}_{\alpha \mathrm{i}}$ activity is unchanged in aged hearts (rat model) and probably do not contribute to the age-related reduction in cardiac $\beta$-AR dysfunction. Interestingly, another group found that $G_{\alpha i}$ content is unchanged while $G_{\alpha i}$ activity is increased in a Guinea-pig aging model (Ferrara et al., 1997a,b). These dissimilar results, most likely, are due to the use of different animal species or time-points (early aging or late aging). Aging is associated with decreased AC activity and cAMP production in the heart (Narayanan and Tucker, 1986; Tang et al., 2011). Cardiac overexpression of AC type 6 ameliorates age-related cardiac dysfunction (increased EF and slope of ESPVR), as showed in HF (see above), through improved calcium uptake (Tang et al., 2011).

Taken together, these studies suggest that $\beta$-AR dysfunction is an important determinant in the age-related cardiac alterations and understanding the specific mechanisms involved would be beneficial for designing specific treatments for the elderly patients with cardiac dysfunction.

\section{CLINICAL POINT OF VIEW AND FUTURE DIRECTIONS}

\section{The Intersection Between Heart Failure and Cardiac Aging}

Over the last few decades, life expectancy has significantly increased although several diseases persist with aging as a risk 
factor. Particularly, despite the improvement in treatments, many elderly people suffer from cardiac problems (HF, valvular diseases, arrhythmias or hypertension) that are much more common in an older fragile heart (Nakou et al., 2016). Interestingly, during both HF and aging, the heart may increase in size and cannot effectively pump blood to the other organs. Cardiac dysfunction is mainly diastolic during aging while it is commonly both systolic and diastolic in HF (different causes could determine the prevalence of one over the other) (Hees et al., 2002; Khouri et al., 2005; Najafi et al., 2016). Nevertheless, there are many similarities between the aging and failing heart: histologically, both have myocyte hypertrophy and cardiac fibrosis and functionally show decreased inotropic reserve and resistance to exercise training (Najafi et al., 2016). In the long-term, age-related heart dysfunction and HF together contribute to the decrease in wellness and performance of normal daily activities for elderly people (De Geest et al., 2004; Kalogeropoulos et al., 2009; Goldwater and Pinney, 2015; Uchmanowicz et al., 2015). In the last decade, epidemiological studies have shown a high incidence and prevalence of HF in the elderly, mainly due to increased life expectancy and improvement in the treatment of $\mathrm{MI}$ and its complications. About $50 \%$ of all HF cases are found in people older than 70 years (Ho et al., 1993; Mozaffarian et al., 2016). The outcomes in elderly patients with HF are modest: older people are seen in a more advanced stage of HF (NYHA class III-IV) and have a 50\% survival rate after a 4-year period (Cacciatore et al., 1998; Pulignano et al., 2002).

\section{$\beta$-Adrenergic Signaling as Therapeutic Target and Diagnostic Tool in Heart Disease}

Many studies have linked the dysfunction of the $\beta$-AR system with the pathogenesis of both HF and senile heart (De Geest et al., 2004). In both conditions, there is an increase in circulating CAs as a result of their reduced plasma clearance, augmented adrenal production, or augmented spillover from the tissues. Moreover, there is an age-dependent and HF-related reduction of the $\mathrm{CA}$ re-uptake transporter localized in the sympathetic nerve terminals in the heart (Leineweber et al., 2002; Leosco et al., 2015; Rengo et al., 2016b). CA levels are significantly correlated with survival and symptoms in patients with HF (Cohn et al., 1984; Grassi et al., 2009). The cardiac $\beta$-AR system is desensitized in aging and the failing heart and $G_{\alpha i}$ activity appears to be altered in both conditions, as well. Although $\beta$-AR dysfunction in $\mathrm{HF}$ is primarily related to GRK2 upregulation, the mechanism involved in age-related $\beta$-AR altered levels/function is still unclear (Xiao et al., 1998). Possibly, GRK2 upregulation in HF is triggered by a stressor event such as MI that prompts acute and robust CA increase while SNS overdrive during aging is gradual and occurs over many years. The importance of $\beta$-ARs in the heart has become greater since many treatments that restore their function and signaling has been demonstrated to be beneficial in the treatment of HF and age-related heart dysfunction (Leosco et al., 2007, 2008, 2013; Rengo et al., 2013). In fact, Leosco et al. (2007, 2008) proved that both physical activity and metoprolol, alone or in combination, improved $\beta$-AR signaling in the aged heart, suggesting a similar effect on $\beta$-AR signaling of chronic treatment with $\beta$-blockers and exercise training. Exercise and $\beta$-blockers have been shown to resensitize cardiac $\beta$-ARs via modulation of cardiac GRK2 levels/activity and G-protein-dependent AC activation (Leosco et al., 2007). In addition, both treatments can downregulate the HF-related SNS overactivity, attenuating adrenal GRK2 overexpression, increasing adrenal $\alpha_{2}$ adrenergic receptor density, and finally reducing CA secretion from the adrenal medulla (Rengo et al., 2010, 2012a, 2013; Femminella et al., 2013). Moreover, physical activity can counteract agedependent cAMP decline via decreased expression of $G_{\alpha i}$ and enhanced isoprenaline-stimulated AC activity (Böhm et al., 1993). Another approach for HF would be to inhibit cardiac GRK2 in order to restore $\beta$-AR downregulation/desensitization. In this regard, GRK2 inhibition via gene therapy is not far from application in a clinical trial. However, our group has recently shown that paroxetine, currently used as SSRI, is a GRK2 inhibitor (Thal et al., 2012; Schumacher et al., 2015; Powell et al., 2016). This latter discovery is encouraging pharmacologists to develop selective small molecules that are able to inhibit GRK2 (Waldschmidt et al., 2016). It has been found that an inverse correlation exists between $\beta$-ARs and GRK2 levels. Intriguingly, cardiac GRK2 is associated to the degree of LV dysfunction, suggesting this kinase can act as a HF progression biomarker (Sato et al., 2015). Moreover, Rengo et al. (2016a) showed that lymphocyte GRK2 protein levels can independently predict prognosis in patients with HF. In fact, lymphocyte GRK2 levels showed an additional prognostic and clinical value over demographic and clinical variables (Rengo et al., 2016a). The same group performed a prospective study in a group of HF patients who underwent rehabilitative treatment through physical activity. Exercise was associated with a significant reduction of lymphocyte GRK2 protein levels and HF patients who did not demonstrate reduced lymphocyte GRK2 protein levels after training presented with a worse outcome (Rengo et al., 2014). Hence, lymphocyte GRK2 may be considered as a promising prognostic marker in HF patients (Travers et al., 2016).

MicroRNAs (miRNAs) are a class of small non-coding RNAs that regulate gene expression during cardiac aging and agerelated CVDs (Kondkar and Abu -Amero, 2015; de Lucia et al., 2017). miRNAs are emerging as a stimulating therapeutic target and have been shown to be stable biomarkers for diagnosis and prognosis during cardiac dysfunction (Kondkar and Abu -Amero, 2015). miR-133 has been recently shown to regulate several components of the $\beta_{1}$-AR transduction signaling and is cardio-protective during pressure overload-induced HF (via decreased apoptosis and fibrosis) (Castaldi et al., 2014).

Despite the increasing effort in basic research on the age-related cardiac dysfunction, clinical research is deeply underestimating the need for studies that include elderly patients. In fact, there is a huge disparity between research and market demand: patients $\geq 65$ are under-represented in all phases of clinical trials, even though in HF, these patients are the primary drug users. In this regard, it would be important to invest (in 
basic and importantly then in clinical research) in development of treatments that will restore $\beta$-AR signaling in both $\mathrm{HF}$ and aging heart.

\section{CONCLUSION}

The aged population is drastically increasing worldwide and it is mandatory to assure an adequate quality life to the elderly suffering from decreased cardiac function. In fact, age-related cardiac alterations and $\mathrm{HF}$, deeply influence the autonomy and the ability to perform daily activities for elderly people. Importantly, $\mathrm{HF}$ is one of the most important comorbidities and causes of hospitalization and/or death for old people in western countries, dramatically affecting the cost of healthcare. Hence, there is a great need for treatments that ameliorate cardiac dysfunction in older people acting against both $\mathrm{HF}$ and cardiac physiological aging. Since $\beta$-AR signaling is dysfunctional in failing as well as aging heart, this pathway is an effective diagnostic and therapeutic target.

\section{REFERENCES}

Agüero, J., Almenar, L., Montó, F., Oliver, E., Sánchez-Lázaro, I., Vicente, D., et al. (2012). Myocardial G protein receptor-coupled kinase expression correlates with functional parameters and clinical severity in advanced heart failure. J. Card. Fail. 18, 53-61. doi: 10.1016/j.cardfail.2011.10.008

Balligand, J. L. (2013). Beta3-adrenoreceptors in cardiovasular diseases: new roles for an "old" receptor. Curr. Drug Deliv. 10, 64-66. doi: 10.2174/ 1567201811310010011

Balligand, J. L. (2016). Cardiac salvage by tweaking with beta-3-adrenergic receptors. Cardiovasc. Res. 111, 128-133. doi: 10.1093/cvr/cvw056

Bathgate-Siryk, A., Dabul, S., Pandya, K., Walklett, K., Rengo, G., Cannavo, A., et al. (2014). Negative impact of $\beta$-arrestin-1 on post-myocardial infarction heart failure via cardiac and adrenal-dependent neurohormonal mechanisms. Hypertension 63, 404-412. doi: 10.1161/HYPERTENSIONAHA.113.02043

Baxter, A. J., Spensley, A., Hildreth, A., Karimova, G., O’Connell, J. E., and Gray, C. S. (2002). Beta blockers in older persons with heart failure: tolerability and impact on quality of life. Heart 88, 611-614. doi: 10.1136/heart.88.6.611

Belge, C., Hammond, J., Dubois-Deruy, E., Manoury, B., Hamelet, J., Beauloye, C., et al. (2014). Enhanced expression of $\beta 3$-adrenoceptors in cardiac myocytes attenuates neurohormone-induced hypertrophic remodeling through nitric oxide synthase. Circulation 129, 451-462. doi: 10.1161/CIRCULATIONAHA. 113.004940

Benjamin, E. J., Blaha, M. J., Chiuve, S. E., Cushman, M., Das, S. R., Deo, R., et al. (2017). Heart disease and stroke statistics-2017 update: a report from the american heart association. Circulation 135, e146-e603. doi: 10.1161/CIR. 0000000000000485

Böhm, M., Dorner, H., Htun, P., Lensche, H., Platt, D., and Erdmann, E. (1993). Effects of exercise on myocardial adenylate cyclase and $\mathrm{Gi}$ alpha expression in senescence. Am. J. Physiol. 264(3 Pt 2), H805-H814. doi: 10.1152/ajpheart.1993. 264.3.H805

Boyle, A. J., Shih, H., Hwang, J., Ye, J., Lee, B., Zhang, Y.,et al. (2011). Cardiomyopathy of aging in the mammalian heart is characterized by myocardial hypertrophy, fibrosis and a predisposition towards cardiomyocyte apoptosis and autophagy. Exp. Gerontol. 46, 549-59. doi: 10.1016/j.exger.2011. 02.010

Bristow, M. R., Ginsburg, R., Minobe, W., Cubicciotti, R. S., Sageman, W. S., Lurie, K., et al. (1982). Decreased catecholamine sensitivity and betaadrenergic-receptor density in failing human hearts. N. Engl. J. Med. 307, 205-211. doi: 10.1056/NEJM198207223070401

Bristow, M. R., Ginsburg, R., Umans, V., Fowler, M., Minobe, W., Rasmussen, R., et al. (1986). Beta 1- and beta 2-adrenergic-receptor subpopulations in

\section{AUTHOR CONTRIBUTIONS}

All authors participated in writing the manuscript and/or revising it critically for important intellectual content.

\section{FUNDING}

This work was supported by National Institutes of Health (NIH P01 HL091799, NIH R37 HL061690, and NIH P01 HL075443 to WK) and American Heart Association (postdoctoral fellowship 17POST33660942 to CdL).

\section{ACKNOWLEDGMENTS}

Figures were created using Servier Medical Art templates, which are licensed under a Creative Commons Attribution 3.0 Uniported License; https://smart.servier.com.

nonfailing and failing human ventricular myocardium: coupling of both receptor subtypes to muscle contraction and selective beta 1-receptor downregulation in heart failure. Circ. Res. 59, 297-309. doi: 10.1161/01.RES.59. 3.297

Brodde, O. E., and Michel, M. C. (1999). Adrenergic and muscarinic receptors in the human heart. Pharmacol. Rev. 51, 651-690.

Brodde, O. E., Michel, M. C., and Zerkowski, H. R. (1995a). Signal transduction mechanisms controlling cardiac contractility and their alterations in chronic heart failure. Cardiovasc. Res. 30, 570-584. doi: 10.1016/S0008-6363(95) 00152-2

Brodde, O. E., Zerkowski, H. R., Schranz, D., Broede-Sitz, A., MichelReher, M., Schäfer-Beisenbusch, E., et al. (1995b). Age-dependent changes in the beta-adrenoceptor-G-protein(s)-adenylyl cyclase system in human right atrium. J. Cardiovasc. Pharmacol. 26, 20-26. doi: 10.1097/00005344-1995070 00-00004

Bundgaard, H., Axelsson, A., Hartvig Thomsen, J., Sørgaard, M., Kofoed, K. F., Hasselbalch, R., et al. (2017). The first-in-man randomized trial of a beta3 adrenoceptor agonist in chronic heart failure: the BEAT-HF trial. Eur. J. Heart Fail. 19, 566-575. doi: 10.1002/ejhf.714

Bundgaard, H., Liu, C. C., Garcia, A., Hamilton, E. J., Huang, Y., Chia, K. K., et al. (2010). $\beta(3)$ adrenergic stimulation of the cardiac $\mathrm{Na}+\mathrm{K}+$ pump by reversal of an inhibitory oxidative modification. Circulation 122, 2699-2708. doi: 10.1161/CIRCULATIONAHA.110.964619

Cacciatore, F., Gallo, C., Ferrara, N., Abete, P., Paolisso, G., Canonico, S., et al. (1998). Morbidity patterns in aged population in southern Italy. A survey sampling. Arch. Gerontol. Geriatr. 26, 201-213. doi: 10.1016/S0167-4943(98) 00003-X

Cannavo, A., Liccardo, D., and Koch, W. J. (2013). Targeting cardiac $\beta$-adrenergic signaling via GRK2 inhibition for heart failure therapy. Front. Physiol. 4:264. doi: 10.3389/fphys.2013.00264

Cannavo, A., Rengo, G., Liccardo, D., Pun, A., Gao, E., George, A. J., et al. (2017). $\beta 1$-blockade prevents post-ischemic myocardial decompensation via $\beta 3$ ar-dependent protective sphingosine-1 phosphate signaling. J. Am. Coll. Cardiol. 70, 182-192. doi: 10.1016/j.jacc.2017.05.020

Castaldi, A., Zaglia, T., Di Mauro, V., Carullo, P., Viggiani, G., Borile, G., et al. (2014). MicroRNA-133 modulates the $\beta 1$-adrenergic receptor transduction cascade. Circ. Res. 115, 273-283. doi: 10.1161/CIRCRESAHA.115. 303252

Cerbai, E., Guerra, L., Varani, K., Barbieri, M., Borea, P. A., and Mugelli, A. (1995). Beta-adrenoceptor subtypes in young and old rat ventricular myocytes: a combined patch-clamp and binding study. Br. J. Pharmacol. 116, 1835-1842. doi: 10.1111/j.1476-5381.1995.tb16671.x 
Chen, J., Levin, L. R., and Buck, J. (2012). Role of soluble adenylyl cyclase in the heart. Am. J. Physiol. Heart Circ. Physiol. 302, H538-H543. doi: 10.1152/ ajpheart.00701.2011

Chesley, A., Lundberg, M. S., Asai, T., Xiao, R. P., Ohtani, S., Lakatta, E. G., et al. (2000). The beta(2)-adrenergic receptor delivers an antiapoptotic signal to cardiac myocytes through $\mathrm{G}(\mathrm{i})$-dependent coupling to phosphatidylinositol 3'-kinase. Circ. Res. 87, 1172-1179. doi: 10.1161/01.RES.87.12.1172

Chiao, Y. A., and Rabinovitch, P. S. (2015). The aging heart. Cold Spring Harb Perspect Med. 5:a025148. doi: 10.1101/cshperspect.a025148

Ciccarelli, M., Chuprun, J. K., Rengo, G., Gao, E., Wei, Z., Peroutka, R. J., et al. (2011). G protein-coupled receptor kinase 2 activity impairs cardiac glucose uptake and promotes insulin resistance after myocardial ischemia. Circulation 123, 1953-1962. doi: 10.1161/CIRCULATIONAHA.110.988642

Cipolletta, E., Campanile, A., Santulli, G., Sanzari, E., Leosco, D., Campiglia, P., et al. (2009). The G protein coupled receptor kinase 2 plays an essential role in beta-adrenergic receptor-induced insulin resistance. Cardiovasc. Res. 84, 407-415. doi: 10.1093/cvr/cvp252

Cohn, J. N., Levine, T. B., Olivari, M. T., Garberg, V., Lura, D., Francis, G. S., et al. (1984). Plasma norepinephrine as a guide to prognosis in patients with chronic congestive heart failure. N. Engl. J. Med. 311, 819-823. doi: 10.1056/ NEJM198409273111303

Conti, S., Cassis, P., and Benigni, A. (2012). Aging and the renin-angiotensin system. Hypertension 60, 878-883. doi: 10.1161/HYPERTENSIONAHA.110. 155895

Crendal, E., Dutheil, F., Naughton, G., McDonald, T., and Obert, P. (2014). Increased myocardial dysfunction, dyssynchrony, and epicardial fat across the lifespan in healthy males. BMC Cardiovasc. Disord. 14:95. doi: 10.1186/1471-2261-14-95

Dai, D. F., Chen, T., Johnson, S. C., Szeto, H., and Rabinovitch, P. S. (2012). Cardiac aging: from molecular mechanisms to significance in human health and disease. Antioxid. Redox. Signal. 16, 1492-1526. doi: 10.1089/ars.2011.4179

Davies, C. H., Ferrara, N., and Harding, S. E. (1996). Beta-adrenoceptor function changes with age of subject in myocytes from non-failing human ventricle. Cardiovasc. Res. 31, 152-156.

De Geest, S., Steeman, E., Leventhal, M. E., Mahrer-Imhof, R., Hengartner-Kopp, B., Conca, A., et al. (2004). Complexity in caring for an ageing heart failure population: concomitant chronic conditions and age related impairments. Eur. J. Cardiovasc. Nurs. 3, 263-270. doi: 10.1016/j.ejcnurse.2004.08.004

de Lucia, C., Femminella, G. D., Gambino, G., Pagano, G., Allocca, E., Rengo, C., et al. (2014). Adrenal adrenoceptors in heart failure. Front. Physiol. 5:246. doi: 10.3389/fphys.2014.00246

de Lucia, C., Femminella, G. D., Rengo, G., Ruffo, A., Parisi, V., Pagano, G., et al. (2013). Risk of acute myocardial infarction after transurethral resection of prostate in elderly. BMC Surg. 13(Suppl. 2):S35. doi: 10.1186/ 1471-2482-13-S2-S35

de Lucia, C., Gambino, G., Petraglia, L., Elia, A., Komici, K., Femminella, G. D., et al. (2018a). Long-term caloric restriction improves cardiac function, remodeling, adrenergic responsiveness, and sympathetic innervation in a model of postischemic heart failure. Circ Heart Fail. 11:e004153. doi: 10.1161/ CIRCHEARTFAILURE.117.004153

de Lucia, C., Komici, K., Borghetti, G., Femminella, G. D., Bencivenga, L., Cannavo, A., et al. (2017). microRNA in cardiovascular aging and age-related cardiovascular diseases. Front. Med. (Lausanne), 4:74. doi: 10.3389/fmed.2017. 00074

de Lucia, C., Wallner, M., Eaton, D. M., Zhao, H., Houser, S. R., and Koch, W. J. (2018b). Echocardiographic strain analysis for the early detection of left ventricular systolic/diastolic dysfunction and dyssynchrony in a mouse model of physiological aging. J. Gerontol. A Biol. Sci. Med. Sci. doi: 10.1093/gerona/ gly139 [Epub ahead of print].

Dei Cas, A., Khan, S. S., Butler, J., Mentz, R. J., Bonow, R. O., Avogaro, A., et al. (2015). Impact of diabetes on epidemiology, treatment, and outcomes of patients with heart failure. JACC Heart Fail. 3, 136-145. doi: 10.1016/j.jchf.2014. 08.004

Dinçer, U. D., Bidasee, K. R., Güner, S., Tay, A., Oz,çelikay, A. T., and Altan, V. M. (2001). The effect of diabetes on expression of beta1-, beta2-, and beta3-adrenoreceptors in rat hearts. Diabetes Metab. Res. Rev. 50, 455-461.
DiNicolantonio, J. J., Fares, H., Niazi, A. K., Chatterjee, S., D'Ascenzo, F., Cerrato, E., et al. (2015). $\beta$-Blockers in hypertension, diabetes, heart failure and acute myocardial infarction: a review of the literature. Open Heart 2:e000230. doi: 10.1136/openhrt-2014-000230

Donckier, J. E., Massart, P. E., Van Mechelen, H., Heyndrickx, G. R., Gauthier, C., and Balligand, J. L. (2001). Cardiovascular effects of beta 3-adrenoceptor stimulation in perinephritic hypertension. Eur. J. Clin. Invest. 31, 681-689. doi: 10.1046/j.1365-2362.2001.00872.x

Dorn, G. W., Tepe, N. M., Lorenz, J. N., Koch, W. J., and Liggett, S. B. (1999). Lowand high-level transgenic expression of beta2-adrenergic receptors differentially affect cardiac hypertrophy and function in Galphaq-overexpressing mice. Proc. Natl. Acad. Sci. U.S.A. 96, 6400-6405. doi: 10.1073/pnas.96.11.6400

Du, X. J., Gao, X. M., Wang, B., Jennings, G. L., Woodcock, E. A., and Dart, A. M. (2000). Age-dependent cardiomyopathy and heart failure phenotype in mice overexpressing beta(2)-adrenergic receptors in the heart. Cardiovasc. Res. 48, 448-454. doi: 10.1016/S0008-6363(00)00187-5

Engelhardt, S., Hein, L., Wiesmann, F., and Lohse, M. J. (1999). Progressive hypertrophy and heart failure in betal-adrenergic receptor transgenic mice. Proc. Natl. Acad. Sci. U.S.A. 96, 7059-7064. doi: 10.1073/pnas.96.12. 7059

Femminella, G. D., de Lucia, C., Iacotucci, P., Formisano, R., Petraglia, L., Allocca, E., et al. (2013). Neuro-hormonal effects of physical activity in the elderly. Front. Physiol. 4:378. doi: 10.3389/fphys.2013.00378

Ferrara, N., Böhm, M., Zolk, O., O'Gara, P., and Harding, S. E. (1997a). The role of Gi-proteins and beta-adrenoceptors in the age-related decline of contraction in guinea-pig ventricular myocytes. J. Mol. Cell Cardiol. 29, 439-448. doi: 10.1006/ jmcc. 1996.0397

Ferrara, N., Davia, K., Abete, P., Rengo, F., and Harding, S. E. (1997b). Alterations in beta-adrenoceptor mechanisms in the aging heart. Relationsh. Heart Fail. Aging (Milano), 9, 391-403.

Ferrara, N., Komici, K., Corbi, G., Pagano, G., Furgi, G., Rengo, C., et al. (2014). $\beta$-adrenergic receptor responsiveness in aging heart and clinical implications. Front. Physiol. 4:396 doi: 10.3389/fphys.2013.00396

Floras, J. S. (2002). The "unsympathetic" nervous system of heart failure. Circulation 105, 1753-1755. doi: 10.1161/01.CIR.0000013788.71817.16

Freeman, K., Lerman, I., Kranias, E. G., Bohlmeyer, T., Bristow, M. R., Lefkowitz, R. J., et al. (2001). Alterations in cardiac adrenergic signaling and calcium cycling differentially affect the progression of cardiomyopathy. J. Clin. Invest. 107, 967-974. doi: 10.1172/JCI12083

$\mathrm{Fu}$, Q., Wang, Q., and Xiang, Y. K. (2017). Insulin and $\beta$ adrenergic receptor signaling: crosstalk in heart. Trends Endocrinol. Metab. 28, 416-427. doi: 10.1016/j.tem.2017.02.002

Fu, Q., Xu, B., Liu, Y., Parikh, D., Li, J., Li, Y., et al. (2014). Insulin inhibits cardiac contractility by inducing a Gi-biased $\beta 2$-adrenergic signaling in hearts. Diabetes Metab. Res. Rev 63, 2676-289. doi: 10.2337/db13-1763

Fu, Q., Xu, B., Parikh, D., Cervantes, D., and Xiang, Y. K. (2015). Insulin induces IRS2-dependent and GRK2-mediated $\beta 2 \mathrm{AR}$ internalization to attenuate $\beta \mathrm{AR}$ signaling in cardiomyocytes. Cell. Signal. 27, 707-715. doi: 10.1016/j.cellsig. 2014.11.018

Gacci, M., Corona, G., Sebastianelli, A., Serni, S., De Nunzio, C., Maggi, M., et al. (2016). Male lower urinary tract symptoms and cardiovascular events: a systematic review and meta-analysis. Eur. Urol. 70, 788-796. doi: 10.1016/j. eururo.2016.07.007

Garcia-Guerra, L., Nieto-Vazquez, I., Vila-Bedmar, R., Jurado-Pueyo, M., Zalba, G., Díez, J., et al. (2010). G protein-coupled receptor kinase 2 plays a relevant role in insulin resistance and obesity. Diabetes Metab. Res. Rev. 59, 2407-2417. doi: $10.2337 / \mathrm{db} 10-0771$

Gauthier, C., Tavernier, G., Charpentier, F., Langin, D., and Le Marec, H. (1996). Functional beta3-adrenoceptor in the human heart. J. Clin. Invest. 98, 556-562. doi: 10.1172/JCI118823

Goldwater, D. S., and Pinney, S. P. (2015). Frailty in advanced heart failure: a consequence of aging or a separate entity? Clin. Med. Insights Cardiol. 9(Suppl. 2), 39-46. doi: 10.4137/CMC.S19698

Grassi, G., Seravalle, G., Quarti-Trevano, F., and Dell'oro, R. (2009). Sympathetic activation in congestive heart failure: evidence, consequences and therapeutic implications. Curr. Vasc Pharmacol. 7, 137-145. doi: $10.2174 / 157016109787455699$ 
Han, C., Rice, M. W., and Cai, D. (2016). Neuroinflammatory and autonomic mechanisms in diabetes and hypertension. Am. J. Physiol. Endocrinol. Metab. 311, E32-E41. doi: 10.1152/ajpendo.00012.2016

Harding, V. B., Jones, L. R., Lefkowitz, R. J., Koch, W. J., and Rockman, H. A. (2001). Cardiac beta ARK1 inhibition prolongs survival and augments beta blocker therapy in a mouse model of severe heart failure. Proc. Natl. Acad. Sci. U.S.A. 98, 5809-5014. doi: 10.1073/pnas.091102398

Hees, P. S., Fleg, J. L., Lakatta, E. G., and Shapiro, E. P. (2002). Left ventricular remodeling with age in normal men versus women: novel insights using three-dimensional magnetic resonance imaging. Am. J. Cardiol. 90, 1231-1236. doi: 10.1016/S0002-9149(02)02840-0

Ho, D., Yan, L., Iwatsubo, K., Vatner, D. E., and Vatner, S. F. (2010). Modulation of beta-adrenergic receptor signaling in heart failure and longevity: targeting adenylyl cyclase type 5. Heart Fail. Rev. 15, 495-512. doi: 10.1007/ s10741-010-9183-5

Ho, K. K., Pinsky, J. L., Kannel, W. B., and Levy, D. (1993). The epidemiology of heart failure: the Framingham Study. J. Am. Coll. Cardiol. 22(4 Suppl. A), 6A-13A. doi: 10.1016/0735-1097(93)90455-A

Iaccarino, G., Barbato, E., Cipolletta, E., De Amicis, V., Margulies, K. B., Leosco, D., et al. (2005). Elevated myocardial and lymphocyte GRK2 expression and activity in human heart failure. Eur. Heart J. 26, 1752-1758. doi: 10.1093/eurheartj/ ehi429

Iyngkaran, P., Anavekar, N., Majoni, W., and Thomas, M. C. (2013). The role and management of sympathetic overactivity in cardiovascular and renal complications of diabetes. Diabetes Metab 39, 290-298. doi: 10.1016/j.diabet. 2013.05.002

Jia, G., DeMarco, V. G., and Sowers, J. R. (2016). Insulin resistance and hyperinsulinaemia in diabetic cardiomyopathy. Nat. Rev. Endocrinol, 12, 144-153. doi: 10.1038/nrendo.2015.216

Kalogeropoulos, A., Georgiopoulou, V., Kritchevsky, S. B., Psaty, B. M., Smith, N. L., Newman, A. B., et al. (2009). Epidemiology of incident heart failure in a contemporary elderly cohort: the health, aging, and body composition study. Arch. Int. Med. 169, 708-715. doi: 10.1001/archinternmed.2009.40

Khouri, M. G., Maurer, M. S., and El-Khoury Rumbarger, L. (2005). Assessment of age-related changes in left ventricular structure and function by freehand three-dimensional echocardiography. Am. J. Geriatr. Cardiol. 14, 118-125. doi: 10.1111/j.1076-7460.2005.03845.x

Koch, W. J., Rockman, H. A., Samama, P., Hamilton, R. A., Bond, R. A., Milano, C. A., et al. (1995). Cardiac function in mice overexpressing the beta-adrenergic receptor kinase or a beta ARK inhibitor. Science 268, 1350-1353. doi: 10.1126/ science. 7761854

Kohout, T. A., Takaoka, H., McDonald, P. H., Perry, S. J., Mao, L., Lefkowitz, R. J., et al. (2001). Augmentation of cardiac contractility mediated by the human beta(3)-adrenergic receptor overexpressed in the hearts of transgenic mice. Circulation 104, 2485-2491. doi: 10.1161/hc4501.098933

Komici, K., Femminella, G. D., de Lucia, C., Cannavo, A., Bencivenga, L., Corbi, G., et al. (2018). Predisposing factors to heart failure in diabetic nephropathy: a look at the sympathetic nervous system hyperactivity. Aging Clin. Exp. Res. doi: 10.1007/s40520-018-0973-2 [Epub ahead of print].

Kondkar, A. A., and Abu -Amero, K. K. (2015). Utility of circulating microRNAs as clinical biomarkers for cardiovascular diseases. Biomed. Res. Int. 2015:821823. doi: $10.1155 / 2015 / 821823$

Lai, N. C., Tang, T., Gao, M. H., Saito, M., Takahashi, T., Roth, D. M., et al. (2008). Activation of cardiac adenylyl cyclase expression increases function of the failing ischemic heart in mice. J. Am. Coll. Cardiol. 51, 1490-1497. doi: 10.1016/j.jacc.2008.01.015

Lefkowitz, R. J. (1998). G protein-coupled receptors. III. New roles for receptor kinases and beta-arrestins in receptor signaling and desensitization. J. Biol. Chem. 273, 18677-18680. doi: 10.1074/jbc.273.30.18677

Leineweber, K., Klapproth, S., Beilfuss, A., Silber, R. E., Heusch, G., Philipp, T., et al. (2003). Unchanged G-protein-coupled receptor kinase activity in the aging human heart. J. Am. Coll. Cardiol. 42, 1487-1492. doi: 10.1016/S0735-1097(03) 01063-5

Leineweber, K., Wangemann, T., Giessler, C., Bruck, H., Dhein, S., Kostelka, M., et al. (2002). Age-dependent changes of cardiac neuronal noradrenaline reuptake transporter (uptake1) in the human heart. J. Am. Coll. Cardiol. 40:1459 doi: 10.1016/S0735-1097(02)02168-X
Leosco, D., Parisi, V., Femminella, G. D., Formisano, R., Petraglia, L., Allocca, E., et al. (2013). Effects of exercise training on cardiovascular adrenergic system. Front. Physiol. 4:348. doi: 10.3389/fphys.2013.00348

Leosco, D., Parisi, V., Pellegrino, T., Pagano, G., Femminella, G. D., Bevilacqua, A., et al. (2015). Alterations of left ventricular deformation and cardiac sympathetic derangement in patients with systolic heart failure: a 3D speckle tracking echocardiography and cardiac ${ }^{123}$ I-MIBG study. Eur. J. Nucl. Med. Mol. Imaging 42, 1601-1611. doi: 10.1007/s00259-015-3054-1

Leosco, D., Rengo, G., Iaccarino, G., Filippelli, A., Lymperopoulos, A., Zincarelli, C., et al. (2007). Exercise training and beta-blocker treatment ameliorate age-dependent impairment of beta-adrenergic receptor signaling and enhance cardiac responsiveness to adrenergic stimulation. Am. J. Physiol. Heart Circ. Physiol. 293, H1596-H603. doi: 10.1152/ajpheart.00308.2007

Leosco, D., Rengo, G., Iaccarino, G., Golino, L., Marchese, M., Fortunato, F., et al. (2008). Exercise promotes angiogenesis and improves beta-adrenergic receptor signalling in the post-ischaemic failing rat heart. Cardiovasc. Res. 78, 385-394. doi: $10.1093 / \mathrm{cvr} / \mathrm{cvm} 109$

Li, X., Matta, S. M., Sullivan, R. D., and Bahouth, S. W. (2014). Carvedilol reverses cardiac insufficiency in AKAP5 knockout mice by normalizing the activities of calcineurin and CaMKII. Cardiovasc. Res. 104, 270-279. doi: 10.1093/cvr/ cru209

Lohse, M. J., Engelhardt, S., and Eschenhagen, T. (2003). What is the role of betaadrenergic signaling in heart failure? Circ. Res. 93, 896-906. doi: 10.1161/01. RES.0000102042.83024.CA

Lucas, E., Jurado-Pueyo, M., Fortuño, M. A., Fernández-Veledo, S., Vila-Bedmar, R., Jiménez-Borreguero, L. J., et al. (2014). Downregulation of G protein-coupled receptor kinase 2 levels enhances cardiac insulin sensitivity and switches on cardioprotective gene expression patterns. Biochim. Biophys. Acta 1842(12 Pt A), 2448-2456. doi: 10.1016/j.bbadis.2014.09.004

Lymperopoulos, A., Rengo, G., and Koch, W. J. (2012). GRK2 inhibition in heart failure: something old, something new. Curr. Pharm. Des. 18, 186-191. doi: 10.2174/138161212799040510

Lymperopoulos, A., Rengo, G., and Koch, W. J. (2013). Adrenergic nervous system in heart failure: pathophysiology and therapy. Circ. Res. 113, 739-753. doi: 10.1161/CIRCRESAHA.113.300308

Lymperopoulos, A., Rengo, G., Zincarelli, C., Kim, J., and Koch, W. J. (2011). Adrenal beta-arrestin 1 inhibition in vivo attenuates post-myocardial infarction progression to heart failure and adverse remodeling via reduction of circulating aldosterone levels. J. Am. Coll. Cardiol. 57, 356-565. doi: 10.1016/j.jacc.2010.08.635

Mandić, M., Drinovec, L., Glisic, S., Veljkovic, N., Nøhr, J., and Vrecl, M. (2014). Demonstration of a direct interaction between $\beta 2$-adrenergic receptor and insulin receptor by BRET and bioinformatics. PLoS One 9:e112664. doi: 10.1371/journal.pone.0112664

Mangmool, S., Denkaew, T., Phosri, S., Pinthong, D., Parichatikanond, W., Shimauchi, T., et al. (2016). Sustained $\beta$ AR stimulation mediates cardiac insulin resistance in a PKA-dependent manner. Mol. Endocrinol. 30, 118-132. doi: 10.1210/me.2015-1201

Mayor, F., Cruces-Sande, M., Arcones, A. C., Vila-Bedmar, R., Briones, A. M., Salaices, M., et al. (2018). G protein-coupled receptor kinase 2 (GRK2) as an integrative signalling node in the regulation of cardiovascular function and metabolic homeostasis. Cell. Signal. 41, 25-32. doi: 10.1016/j.cellsig.2017.04.002

McCrink, K. A., Maning, J., Vu, A., Jafferjee, M., Marrero, C., Brill, A., et al. (2017). $\beta$-Arrestin2 Improves post-myocardial infarction heart failure via sarco[endo]plasmic reticulum $\mathrm{Ca}(2+)$-ATPase-dependent positive inotropy in cardiomyocytes. Hypertension 70, 972-981 doi: 10.1161/HYPERTENSIONAHA.117.09817

Mendzef, S. D., and Slovinski, J. R. (2004). Neurohormones and heart failure. Nurs. Clin. N. Am. 39, 845-861. doi: 10.1016/j.cnur.2004.07.004

Miyoshi, T., Nakamura, K., Yoshida, M., Miura, D., Oe, H., Akagi, S., et al. (2014). Effect of vildagliptin, a dipeptidyl peptidase 4 inhibitor, on cardiac hypertrophy induced by chronic beta-adrenergic stimulation in rats. Cardiovasc Diabetol, 13:43. doi: $10.1186 / 1475-2840-13-43$

Moniotte, S., Kobzik, L., Feron, O., Trochu, J. N., Gauthier, C., and Balligand, J. L. (2001). Upregulation of beta(3)-adrenoceptors and altered contractile response to inotropic amines in human failing myocardium. Circulation 103, 1649-1655. doi: 10.1161/01.CIR.103.12.1649 
Morimoto, A., Hasegawa, H., Cheng, H. J., Little, W. C., and Cheng, C. P. (2004). Endogenous beta3-adrenoreceptor activation contributes to left ventricular and cardiomyocyte dysfunction in heart failure. Am. J. Physiol. Heart Circ. Physiol. 286, H2425-H2433. doi: 10.1152/ajpheart.01045.2003

Morisco, C., Condorelli, G., Trimarco, V., Bellis, A., Marrone, C., Sadoshima, J., et al. (2005). Akt mediates the cross-talk between beta-adrenergic and insulin receptors in neonatal cardiomyocytes. Circ. Res. 96, 180-188. doi: 10.1161/01. RES.0000152968.71868.c3

Mozaffarian, D., Benjamin, E. J., Go, A. S., Arnett, D. K., Blaha, M. J., Cushman, M. et al. (2016). Heart disease and stroke statistics-2016 update: a report from the american heart association. Circulation 133, e38-e360. doi: 10.1161/CIR. 0000000000000350

Myagmar, B. E., Flynn, J. M., Cowley, P. M., Swigart, P. M., Montgomery, M. D., Thai, K., et al. (2017). Adrenergic receptors in individual ventricular myocytes: the beta- 1 and alpha-1b are in all cells, the alpha-1a is in a subpopulation, and the beta- 2 and beta-3 are mostly absent. Circ. Res. 120, 1103-1115. doi: 10.1161/CIRCRESAHA.117.310520

Najafi, A., Sequeira, V., Kuster, D. W., and van der Velden, J. (2016). $\beta$-adrenergic receptor signalling and its functional consequences in the diseased heart. Eur. J. Clin. Invest. 46, 362-374. doi: 10.1111/eci.12598

Nakou, E. S., Parthenakis, F. I., Kallergis, E. M., Marketou, M. E., Nakos, K. S., and Vardas, P. E. (2016). Healthy aging and myocardium: a complicated process with various effects in cardiac structure and physiology. Int. J. Cardiol. 209, 167-175. doi: 10.1016/j.ijcard.2016.02.039

Namba, M., Katsuno, T., Kusunoki, Y., Matsuo, T., Miuchi, M., and Miyagawa, J. (2013). New strategy for the treatment of type 2 diabetes mellitus with incretin-based therapy. Clin. Exp. Nephrol 17, 10-15. doi: 10.1007/s101 57-012-0709-0

Narayanan, N., and Tucker, L. (1986). Autonomic interactions in the aging heart: age-associated decrease in muscarinic cholinergic receptor mediated inhibition of beta-adrenergic activation of adenylate cyclase. Mech. Ageing Dev. 34, 249-259. doi: 10.1016/0047-6374(86)90077-1

Nguyen, M. N., Kiriazis, H., Ruggiero, D., Gao, X. M., Su, Y., Jian, A., et al. (2015). Spontaneous ventricular tachyarrhythmias in $\beta 2$-adrenoceptor transgenic mice in relation to cardiac interstitial fibrosis. Am. J. Physiol. Heart Circ. Physiol. 309, H946-H957. doi: 10.1152/ajpheart.00405.2015

Niccoli, T., and Partridge, L. (2012). Ageing as a risk factor for disease. Curr. Biol. 22, R741-R752. doi: 10.1016/j.cub.2012.07.024

Niu, X., Watts, V. L., Cingolani, O. H., Sivakumaran, V., Leyton-Mange, J. S., Ellis, C. L., et al. (2012). Cardioprotective effect of beta-3 adrenergic receptor agonism: role of neuronal nitric oxide synthase. J. Am. Coll. Cardiol. 59, 1979-1987. doi: 10.1016/j.jacc.2011.12.046

Noma, T., Lemaire, A., Naga Prasad, S. V., Barki-Harrington, L., Tilley, D. G., Chen, J., et al. (2007). Beta-arrestin-mediated betal-adrenergic receptor transactivation of the EGFR confers cardioprotection. J. Clin. Invest. 117, 2445-2458. doi: 10.1172/JCI31901

North, B. J., and Sinclair, D. A. (2012). The intersection between aging and cardiovascular disease. Circ. Res. 110, 1097-1108. doi: 10.1161/CIRCRESAHA. 111.246876

Okumura, S., Takagi, G., Kawabe, J., Yang, G., Lee, M. C., Hong, C., et al. (2003). Disruption of type 5 adenylyl cyclase gene preserves cardiac function against pressure overload. Proc. Natl. Acad. Sci. U.S.A. 100, 9986-9990. doi: 10.1073/ pnas. 1733772100

Okumura, S., Vatner, D. E., Kurotani, R., Bai, Y., Gao, S., Yuan, Z., et al. (2007). Disruption of type 5 adenylyl cyclase enhances desensitization of cyclic adenosine monophosphate signal and increases Akt signal with chronic catecholamine stress. Circulation 116, 1776-1783. doi: 10.1161/ CIRCULATIONAHA.107.698662

Packer, M., Bristow, M. R., Cohn, J. N., Colucci, W. S., Fowler, M. B., Gilbert, E. M., et al. (1996). The effect of carvedilol on morbidity and mortality in patients with chronic heart failure. U.S. Carvedilol Heart Failure Study Group. N. Engl. J. Med. 334, 1349-1355. doi: 10.1056/NEJM199605233342101

Packiriswamy, N., and Parameswaran, N. (2015). G-protein-coupled receptor kinases in inflammation and disease. Genes Immun. 16, 367-377. doi: 10.1038/ gene. 2015.26

Paolisso, G., De Riu, S., Marrazzo, G., Verza, M., Varricchio, M., and D’Onofrio, F. (1991). Insulin resistance and hyperinsulinemia in patients with chronic congestive heart failure. Metabolism 40, 972-977. doi: 10.1016/0026-0495(91) 90075-8

Parati, G., and Esler, M. (2012). The human sympathetic nervous system: its relevance in hypertension and heart failure. Eur. Heart J. 33, 1058-1066. doi: 10.1093/eurheartj/ehs041

Patel, P. A., Tilley, D. G., and Rockman, H. A. (2008). Beta-arrestin-mediated signaling in the heart. Circ. J. 72, 1725-1729. doi: 10.1253/circj.CJ-08-0734

Penela, P., Murga, C., Ribas, C., Tutor, A. S., Peregrín, S., and Mayor, F. (2006). Mechanisms of regulation of $G$ protein-coupled receptor kinases (GRKs) and cardiovascular disease. Cardiovasc. Res. 69, 46-56. doi: 10.1016/j.cardiores. 2005.09.011

Pepper, G. S., and Lee, R. W. (1999). Sympathetic activation in heart failure and its treatment with beta-blockade. Arch. Intern. Med. 159, 225-234. doi: 10.1001/ archinte.159.3.225

Ponikowski, P., Anker, S. D., AlHabib, K. F., Cowie, M. R., Force, T. L., Hu, S., et al. (2014). Heart failure: preventing disease and death worldwide. ESC Heart Fail. 1, 4-25 doi: 10.1002/ehf2.12005

Post, S. R., Aguila-Buhain, O., and Insel, P. A. (1996). A key role for protein kinase $A$ in homologous desensitization of the beta 2 -adrenergic receptor pathway in S49 lymphoma cells. J. Biol. Chem. 271, 895-900. doi: 10.1074/jbc.271.2.895

Post, S. R., Hammond, H. K., and Insel, P. A. (1999). Beta-adrenergic receptors and receptor signaling in heart failure. Annu. Rev. Pharmacol. Toxicol. 39, 343-360. doi: 10.1146/annurev.pharmtox.39.1.343

Powell, J. M., Ebin, E., Borzak, S., Lymperopoulos, A., and Hennekens, C. H. (2016). Hypothesis: paroxetine, a G protein-coupled receptor kinase 2 (GRK2) inhibitor reduces morbidity and mortality in patients with heart failure. J. Cardiovasc. Pharmacol. Ther. doi: 10.1177/1074248416644350 [Epub ahead of print].

Pulignano, G., Del Sindaco, D., Tavazzi, L., Lucci, D., Gorini, M., Leggio, F., et al. (2002). Clinical features and outcomes of elderly outpatients with heart failure followed up in hospital cardiology units: data from a large nationwide cardiology database (IN-CHF Registry). Am. Heart. J. 143, 45-55. doi: 10.1067/ mhj.2002.119608

Raake, P. W., Schlegel, P., Ksienzyk, J., Reinkober, J., Barthelmes, J., Schinkel, S., et al. (2013). AAV6.ßARKct cardiac gene therapy ameliorates cardiac function and normalizes the catecholaminergic axis in a clinically relevant large animal heart failure model. Eur. Heart J. 34, 1437-1447. doi: 10.1093/eurheartj/ ehr447

Raake, P. W., Vinge, L. E., Gao, E., Boucher, M., Rengo, G., Chen, X., et al. (2008). G protein-coupled receptor kinase 2 ablation in cardiac myocytes before or after myocardial infarction prevents heart failure. Circ. Res. 103, 413-422. doi: 10.1161/CIRCRESAHA.107.168336

Rengo, G., Galasso, G., Femminella, G. D., Parisi, V., Zincarelli, C., Pagano, G., et al. (2014). Reduction of lymphocyte $G$ protein-coupled receptor kinase-2 (GRK2) after exercise training predicts survival in patients with heart failure. Eur. J. Preven. Cardiol. 21, 4-11. doi: 10.1177/2047487313491656

Rengo, G., Leosco, D., Zincarelli, C., Marchese, M., Corbi, G., Liccardo, D., et al. (2010). Adrenal GRK2 lowering is an underlying mechanism for the beneficial sympathetic effects of exercise training in heart failure. Am. J. Physiol. Heart Circ. Physiol. 298, H2032-H2038. doi: 10.1152/ajpheart.00702.2009

Rengo, G., Lymperopoulos, A., and Koch, W. J. (2009a). Future g protein-coupled receptor targets for treatment of heart failure. Curr. Treat. Options Cardiovasc. Med. 11, 328-338. doi: 10.1007/s11936-009-0033-5

Rengo, G., Lymperopoulos, A., Zincarelli, C., Donniacuo, M., Soltys, S., Rabinowitz, J. E., et al. (2009b). Myocardial adeno-associated virus serotype 6-betaARKct gene therapy improves cardiac function and normalizes the neurohormonal axis in chronic heart failure. Circulation 119, 89-98. doi: 10.1161/CIRCULATIONAHA.108.803999

Rengo, G., Lymperopoulos, A., Zincarelli, C., Femminella, G., Liccardo, D., Pagano, G., et al. (2012a). Blockade of $\beta$-adrenoceptors restores the GRK2mediated adrenal $\alpha(2)$-adrenoceptor-catecholamine production axis in heart failure. Br. J. Pharmacol. 166, 2430-2440. doi: 10.1111/j.1476-5381.2012. 01972.x

Rengo, G., Pagano, G., Filardi, P. P., Femminella, G. D., Parisi, V., Cannavo, A., et al. (2016a). Prognostic value of lymphocyte $G$ protein-coupled receptor kinase-2 protein levels in patients with heart failure. Circ. Res. 118, 1116-1124. doi: 10.1161/CIRCRESAHA.115.308207 
Rengo, G., Pagano, G., Paolillo, S., de Lucia, C., Femminella, G. D., Liccardo, D., et al. (2015). Impact of diabetes mellitus on lymphocyte GRK2 protein levels in patients with heart failure. Eur. J. Clin. Invest. 45, 187-195. doi: 10.1111/eci. 12395

Rengo, G., Pagano, G., Vitale, D. F., Formisano, R., Komici, K., Petraglia, L., et al. (2016b). Impact of aging on cardiac sympathetic innervation measured by (123)I-mIBG imaging in patients with systolic heart failure. Eur. J. Nucl. Med. Mol. Imaging. 43, 2392-2400. doi: 10.1007/s00259-016-3432-3

Rengo, G., Parisi, V., Femminella, G. D., Pagano, G., de Lucia, C., Cannavo, A., et al. (2013). Molecular aspects of the cardioprotective effect of exercise in the elderly. Aging Clin. Exp. Res. 25, 487-497. doi: 10.1007/s40520-013-0117-7

Rengo, G., Perrone-Filardi, P., Femminella, G. D., Liccardo, D., Zincarelli, C., de Lucia, C., et al. (2012b). Targeting the $\beta$-adrenergic receptor system through G-protein-coupled receptor kinase 2: a new paradigm for therapy and prognostic evaluation in heart failure: from bench to bedside. Circ. Heart Fail. 5, 385-391. doi: 10.1161/CIRCHEARTFAILURE.112.966895

Rengo, G., Zincarelli, C., Femminella, G. D., Liccardo, D., Pagano, G., de Lucia, C., et al. (2012c). Myocardial $\beta(2)$-adrenoceptor gene delivery promotes coordinated cardiac adaptive remodelling and angiogenesis in heart failure. Br. J. Pharmacol. 166, 2348-2361. doi: 10.1111/j.1476-5381.2012. 01954.x

Rockman, H. A., Koch, W. J., and Lefkowitz, R. J. (2002). Lefkowitz: seventransmembrane-spanning receptors and heart function. Nature 415, 206-212. doi: 10.1038/415206a

Sato, P. Y., Chuprun, J. K., Schwartz, M., and Koch, W. J. (2015). The evolving impact of $\mathrm{g}$ protein-coupled receptor kinases in cardiac health and disease. Physiol. Rev. 95, 377-404. doi: 10.1152/physrev.00015.2014

Schiattarella, G. G., Cattaneo, F., Pironti, G., Magliulo, F., Carotenuto, G., Pirozzi, M., et al. (2016). Akap1 deficiency promotes mitochondrial aberrations and exacerbates cardiac injury following permanent coronary ligation via enhanced mitophagy and apoptosis. PLoS One 11:e0154076. doi: 10.1371/ journal.pone.0154076

Schuetz, P., Castro, P., and Shapiro, N. I. (2011). Diabetes and sepsis: preclinical findings and clinical relevance. Diabetes Care 34, 771-778. doi: 10.2337/dc101185

Schumacher, S. M., Gao, E., Zhu, W., Chen, X., Chuprun, J. K., Feldman, A. M., et al. (2015). Paroxetine-mediated GRK2 inhibition reverses cardiac dysfunction and remodeling after myocardial infarction. Sci. Transl. Med. 7:277ra31. doi: 10.1126/scitranslmed.aaa0154

Seeland, U., Selejan, S., Engelhardt, S., Müller, P., Lohse, M. J., and Böhm, M. (2007). Interstitial remodeling in betal-adrenergic receptor transgenic mice. Basic Res. Cardiol. 102, 183-193. doi: 10.1007/s00395-006-0635-y

Shah, A. S., White, D. C., Emani, S., Kypson, A. P., Lilly, R. E., Wilson, K., et al. (2001). In vivo ventricular gene delivery of a beta-adrenergic receptor kinase inhibitor to the failing heart reverses cardiac dysfunction. Circulation 103, 1311-1316. doi: 10.1161/01.CIR.103.9.1311

Shakib, S., and Clark, R. A. (2016). Heart failure pharmacotherapy and supports in the elderly - A short review. Curr. Cardiol. Rev. 12, 180-185. doi: 10.2174/ $1573403 X 12666160622102802$

Shenoy, S. K., and Lefkowitz, R. J. (2011). $\beta$-Arrestin-mediated receptor trafficking and signal transduction. Trends Pharmacol. Sci. 32, 521-533. doi: 10.1016/j.tips. 2011.05.002

Shimizu, I., Yoshida, Y., Katsuno, T., Tateno, K., Okada, S., Moriya, J., et al. (2012). p53-induced adipose tissue inflammation is critically involved in the development of insulin resistance in heart failure. Cell Metab. 15, 51-64. doi: 10.1016/j.cmet.2011.12.006

Silver, M. A., Horton, D. P., Ghali, J. K., and Elkayam, U. (2002). Effect of nesiritide versus dobutamine on short-term outcomes in the treatment of patients with acutely decompensated heart failure. J. Am. Coll. Cardiol. 39, 798-803. doi: 10.1016/S0735-1097(01)01818-6

Song, X., Zheng, X., Malbon, C. C., and Wang, H. (2001). Galpha i2 enhances in vivo activation of and insulin signaling to GLUT4. J. Biol. Chem. 276, 34651-34658. doi: 10.1074/jbc.M105894200

Strait, J. B., and Lakatta, E. G. (2012). Aging-associated cardiovascular changes and their relationship to heart failure. Heart Fail Clin. 8, 143-164. doi: 10.1016/j.hfc. 2011.08.011

Tang, T., Hammond, H. K., Firth, A., Yang, Y., Gao, M. H., Yuan, J. X., et al. (2011). Adenylyl cyclase 6 improves calcium uptake and left ventricular function in aged hearts. J. Am. Coll. Cardiol. 57, 1846-1855. doi: 10.1016/j.jacc.2010. 11.052

Tasyurek, H. M., Altunbas, H. A., Balci, M. K., and Sanlioglu, S. (2014). Incretins: their physiology and application in the treatment of diabetes mellitus. Diabetes Metab. Res. Rev 30, 354-371. doi: 10.1002/dmrr.2501

Tevaearai, H. T., Eckhart, A. D., Walton, G. B., Keys, J. R., Wilson, K., and Koch, W. J. (2002). Myocardial gene transfer and overexpression of beta2-adrenergic receptors potentiates the functional recovery of unloaded failing hearts. Circulation 106, 124-129. doi: 10.1161/01.CIR.0000020220.79105.FD

Thal, D. M., Homan, K. T., Chen, J., Wu, E. K., Hinkle, P. M., Huang, Z. M., et al. (2012). Paroxetine is a direct inhibitor of $\mathrm{g}$ protein-coupled receptor kinase 2 and increases myocardial contractility. ACS Chem. Biol. 7, 1830-1839. doi: $10.1021 / \mathrm{cb} 3003013$

Tilley, D. G. (2011). G protein-dependent and G protein-independent signaling pathways and their impact on cardiac function. Circ. Res. 109, 217-230. doi: 10.1161/CIRCRESAHA.110.231225

Travers, J. G., Schafer, A. E., and Blaxall, B. C. (2016). GRK2 in lymphocytes: expanding the arsenal of heart failure prognostics. Circ. Res. 118, 1049-1051. doi: 10.1161/CIRCRESAHA.116.308542

Tsuchimochi, S., Tamaki, N., Tadamura, E., Kawamoto, M., Fujita, T., Yonekura, Y., et al. (1995). Age and gender differences in normal myocardial adrenergic neuronal function evaluated by iodine-123-MIBG imaging. J. Nucl. Med. 36, 969-974.

Uchmanowicz, I., Wleklik, M., and Gobbens, R. J. (2015). Frailty syndrome and self-care ability in elderly patients with heart failure. Clin. Interv. Aging 10, 871-877. doi: 10.2147/CIA.S83414

Ungerer, M., Böhm, M., Elce, J. S., Erdmann, E., and Lohse, M. J. (1993). Altered expression of beta-adrenergic receptor kinase and beta 1-adrenergic receptors in the failing human heart. Circulation 87, 454-463. doi: 10.1161/01.CIR.87. 2.454

Vila-Bedmar, R., Cruces-Sande, M., Lucas, E., Willemen, H. L., Heijnen, C. J., Kavelaars, A., et al. (2015). Reversal of diet-induced obesity and insulin resistance by inducible genetic ablation of GRK2. Sci. Signal. 8:ra73. doi: $10.1126 /$ scisignal.aaa4374

Vinge, L. E., Raake, P. W., and Koch, W. J. (2008). Gene therapy in heart failure. Circ. Res. 102, 1458-1470. doi: 10.1161/CIRCRESAHA.108.173195

Waldschmidt, H. V., Homan, K. T., Cato, M. C., Cruz-Rodríguez, O., Cannavo, A., Wilson, M. W., et al. (2017). Structure-based design of highly selective and potent g protein-coupled receptor kinase 2 inhibitors based on paroxetine. J. Med. Chem. 60, 3052-3069. doi: 10.1021/acs.jmedchem. $7 \mathrm{~b} 00112$

Waldschmidt, H. V., Homan, K. T., Cruz-Rodríguez, O., Cato, M. C., WaningerSaroni, J., Larimore, K. M., et al. (2016). Structure-based design, synthesis, and biological evaluation of highly selective and potent $\mathrm{G}$ protein-coupled receptor kinase 2 inhibitors. J. Med. Chem. 59, 3793-3807. doi: 10.1021/acs.jmedchem. 5 b02000

Wang, Y., Jin, L., Song, Y., Zhang, M., Shan, D., Liu, Y., et al. (2017). $\beta$-arrestin 2 mediates cardiac ischemia-reperfusion injury via inhibiting GPCR-independent cell survival signalling. Cardiovasc. Res. 113, 1615-1626. doi: 10.1093/cvr/ cvx147

Watari, K., Nakaya, M., Nishida, M., Kim, K. M., and Kurose, H. (2013). $\beta$-arrestin2 in infiltrated macrophages inhibits excessive inflammation after myocardial infarction. PLoS One 8:e68351. doi: 10.1371/journal.pone. 0068351

White, D. C., Hata, J. A., Shah, A. S., Glower, D. D., Lefkowitz, R. J., and Koch, W. J. (2000). Preservation of myocardial beta-adrenergic receptor signaling delays the development of heart failure after myocardial infarction. Proc. Natl. Acad. Sci. U.S.A. 97, 5428-5433. doi: 10.1073/pnas.090091197

White, M., Roden, R., Minobe, W., Khan, M. F., Larrabee, P., Wollmering, M., et al. (1994). Age-related changes in beta-adrenergic neuroeffector systems in the human heart. Circulation 90, 1225-1238. doi: 10.1161/01.CIR.90.3. 1225

Woodall, M. C., Ciccarelli, M., Woodall, B. P., and Koch, W. J. (2014). G proteincoupled receptor kinase 2: a link between myocardial contractile function and cardiac metabolism. Circ. Res. 114, 1661-1670. doi: 10.1161/CIRCRESAHA. 114.300513

Xiao, R. P., Tomhave, E. D., Wang, D. J., Ji, X., Boluyt, M. O., Cheng, H., et al. (1998). Age-associated reductions in cardiac beta1- and beta2-adrenergic 
responses without changes in inhibitory $\mathrm{G}$ proteins or receptor kinases. J. Clin. Invest. 101, 1273-1282. doi: 10.1172/JCI1335

Yan, L., Vatner, S. F., and Vatner, D. E. (2014). Disruption of type 5 adenylyl cyclase prevents $\beta$-adrenergic receptor cardiomyopathy: a novel approach to $\beta$-adrenergic receptor blockade. Am. J. Physiol. Heart Circ. Physiol. 307, H1521-H1528. doi: 10.1152/ajpheart.00491.2014

Zhu, W., Woo, A. Y., Zhang, Y., Cao, C. M., and Xiao, R. P. (2011). $\beta$-adrenergic receptor subtype signaling in the heart: from bench to the bedside. Curr. Top. Membr. 67, 191-204. doi: 10.1016/B978-0-12-384921-2.00009-4

Ziaeian, B., and Fonarow, G. C. (2016). Epidemiology and aetiology of heart failure. Nat. Rev. Cardiol. 13, 368-378. doi: 10.1038/nrcardio.2016.25
Conflict of Interest Statement: The authors declare that the research was conducted in the absence of any commercial or financial relationships that could be construed as a potential conflict of interest.

Copyright (c) 2018 de Lucia, Eguchi and Koch. This is an open-access article distributed under the terms of the Creative Commons Attribution License (CC BY). The use, distribution or reproduction in other forums is permitted, provided the original author(s) and the copyright owner(s) are credited and that the original publication in this journal is cited, in accordance with accepted academic practice. No use, distribution or reproduction is permitted which does not comply with these terms. 